\author{
UNIVERSIDADE DE SÃO PAULO - USP \\ FACULDADE DE ECONOMIA, ADMINISTRAÇÃO E CONTABILIDADE \\ DEPARTAMENTO DE ECONOMIA \\ PROGRAMA DE PÓS-GRADUAÇÃO EM ECONOMIA
}

\title{
Air Pollution Consequences in São Paulo: Evidence for Health
}

\section{Consequências da Poluição do Ar em São Paulo: Evidências para Saúde}

Bruna Morais Guidetti

Orientadora: Paula Carvalho Pereda

São Paulo

2018 
Prof. Dr. Vahan Agopyan

Reitor da Universidade de São Paulo

Prof. Dr. Adalberto Américo Fischmann

Diretor da Faculdade de Economia, Administração e Contabilidade

Prof. Dr. Eduardo Amaral Haddad

Chefe do Departamento de Economia

Prof. Dr. Ariaster Baumgratz Chimeli

Coordenador do Programa de Pós-Graduação em Economia 


\section{Air Pollution Consequences in São Paulo: \\ Evidence for Health}

\section{Consequências da Poluição do Ar em São Paulo: Evidências para Saúde}

Dissertação apresentada ao Departamento de Economia da Faculdade de Economia, Administração e Contabilidade da Universidade de São Paulo como requisito parcial para a obtenção do título de Mestre em Ciências.

Orientadora: Paula Carvalho Pereda

Versão Original

São Paulo

2018 
FICHA CATALOGRÁFICA

Elaborada por Rafael Mielli Rodrigues - CRB-8/7286

Seção de Processamento Técnico do SBD/FEA/USP

\section{Guidetti, Bruna Morais}

Air pollution consequences in São Paulo: evidence for health / Bruna Morais Guidetti. - São Paulo, 2018.

$72 \mathrm{p}$.

Dissertação (Mestrado) - Universidade de São Paulo, 2018.

Orientador: Paula Carvalho Pereda.

1. Economia da saúde 2. Crianças 3. Poluição do ar 4. Vento I. Universidade de São Paulo. Faculdade de Economia, Administração e Contabilidade. II. Título.

CDD - 330.1556 


\section{Acknowledgements}

Agradeço ao CNPq e à Fundação de Amparo à Pesquisa do Estado de São Paulo (FAPESP) pelo apoio prestado, a última pelo processo 2017/08472-0.

Agradeço à professora Paula Pereda pela orientação e dedicação, e ao Edson Severnini pela recepção e contribuição durante o período que passei na Carnegie Mellon University. Agradeço também ao Núcleo de Economia Regional e Urbana da Universidade de São Paulo (NEREUS) pelo suporte e aprendizado durante o mestrado.

Por fim, agradeço à minha família, em especial a meus pais e irmãs, pelo apoio incondicional, força e incentivo. Agradeço também ao Cristiano, pelo apoio e companheirismo, e a todos meus amigos, em especial àqueles que me acompanharam de perto nos últimos anos. 

"Como o tempo custa a passar quando a gente espera! Principalmente quando venta. Parece que o vento maneia o tempo."

(Érico Veríssimo) 



\section{Abstract}

Air pollution causes negative externalities on human health, especially on vulnerable groups such as children. We look at hospitalizations due to respiratory diseases for children in São Paulo Metropolitan Area (SPMA) between 2015 and 2017 as consequence of variation in particulate matter (PM 10) levels. We use wind speed as instrument for PM to deal with the endogeneity of air pollution exposure, considering that non-stationary sources of pollution are predominant in the region, which is among the ten largest metropolitan areas in the world. The results show that air pollution positively affects hospitalizations due to all respiratory, pneumonia and asthma in the short term for children between one and five years old. For infant, we only find impact on influenza admission. Additional results suggest the Brazilian public health system is absorbing the increase in hospitalization due to this health shock. Furthermore, delay to visit the hospital may be underestimating our results. We also run a multi-pollutant model, including ozone (O3) as pollutant and solar radiation as instrument. Our coefficients of PM 10 are robust to this specification and we find no impact of O3 on health.

Key-words: Health economics, Children, Air Pollution, Wind. 



\section{Resumo}

A poluição do ar causa externalidade negativa na saúde humana, especialmente em grupos vulneráveis como crianças. Olhamos para internações por doenças respiratórias em crianças na Região Metropolitana de São Paulo (RMSP) entre 2015 e 2017, em consequência de variações nos níveis de material particulado (MP 10). Usamos a velocidade do vento como instrumento para MP, a fim de lidar com a endogeneidade da exposição à poluição, considerando que as fontes não estacionárias são predominantes na RMSP, que está entre as dez maiores regiões metropolitanas no mundo. Os resultados mostram que a poluição do ar afeta positivamente internações por todas as doenças respiratórias, pneumonia e asma no curto prazo para crianças entre um e cinco anos. Para bebês, apenas encontramos impacto nas internações por influenza. Resultados adicionais sugerem que o sistema público de saúde brasileiro está absorvendo o aumento de hospitalizações devido a esse choque de saúde. Também rodamos um modelo com múltiplos poluentes, adicionando ozônio (O3) como poluente e radiação solar como instrumento. Os coeficientes de MP 10 são robustos a essa especificação e não encontramos impacto de O3 na saúde.

Palavras-chave: Economia da saúde, Crianças, Poluição do Ar, Vento. 



\section{List of Figures}

Figure 1 - Hospital beds and physicians per 1000 inhabitants . . . . . . . . . . . . 19

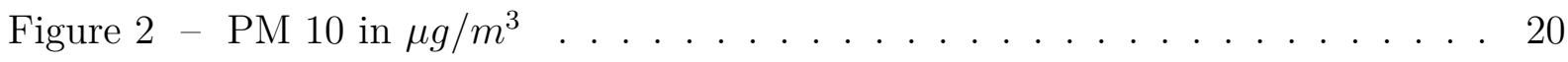

Figure 3 - Hospital beds per 1000 inhabitants by bed location and metropolitan area . . . . . . . . . . . . . . . . . . 26

Figure 4 - Monitors and districts within $5 \mathrm{~km} \ldots \ldots . \ldots . \ldots 31$

Figure 5 - Average and maximum PM, and number of days above WHO guidelines 32

Figure 6 - Average and maximum O3, and number of days above WHO guidelines 33

Figure 7 - Hospitalization rate and monitors location . . . . . . . . . . . 34

Figure 8 - Expressways and highways . . . . . . . . . . . . . 34

Figure 9 - Duration of hospitalization histogram . . . . . . . . . . . . 35

Figure 10 - Ozone formation by season at University City area in SPMA . . . . . 72 



\section{List of Tables}

Table 1 - General characteristics by year . . . . . . . . . . . . . 33

Table 2 - First stage . . . . . . . . . . . . . . . . . . 39

Table 3 - Second stage . . . . . . . . . . . . . . . . . . . 44 4

Table 4 - Second stage - other diseases . . . . . . . . . . . . . 44

Table 5 - Allocation between SUS and non-SUS hospitals - respiratory diseases . . 46

Table 6 - Allocation between SUS and non-SUS hospitals - other diseases . . . . . 47

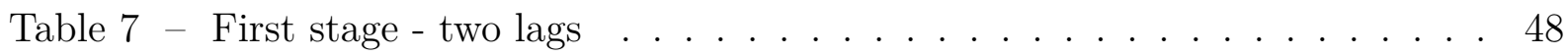

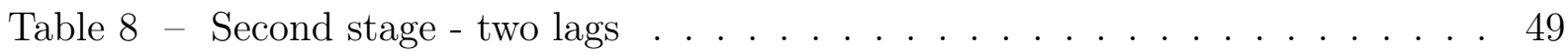

Table 9 - First stage - PM 10 and $\mathrm{O} 3 \ldots \ldots \ldots \ldots \ldots$

Table 10 - Second stage - PM 10 and $\mathrm{O} 3 \ldots \ldots \ldots \ldots 2$

Table 11 - First stage - placebo . . . . . . . . . . . . . . . . . 53

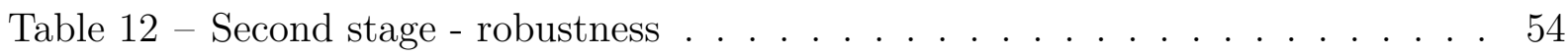

Table 1 - First stage $-3 \mathrm{~km} \ldots \ldots \ldots \ldots \ldots \ldots$

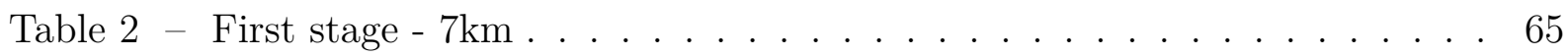

Table 3 - First stage $-10 \mathrm{~km} \ldots \ldots \ldots \ldots \ldots 6 \ldots$

Table 4 - Second stage $-3 \mathrm{~km} \ldots \ldots \ldots \ldots$. . . . . . . . . . 67

Table 5 - Second stage $-7 \mathrm{~km} \ldots \ldots \ldots \ldots$

Table 6 - Second stage $-10 \mathrm{~km} \ldots \ldots \ldots$. . . . . . . . . . . . 69

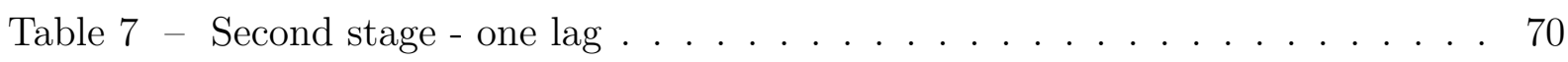

Table 8 - Second stage - three lags $\ldots \ldots \ldots \ldots 71$ 



\section{Contents}

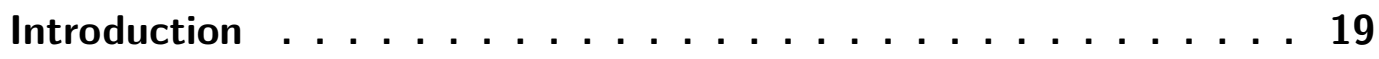

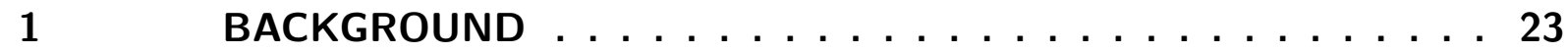

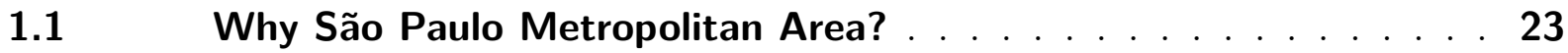

1.2 The Brazilian health system $\ldots \ldots \ldots \ldots \ldots$

$1.3 \quad$ Air pollution and human health $\ldots \ldots \ldots \ldots$

2 METHODOLOGY ..................29

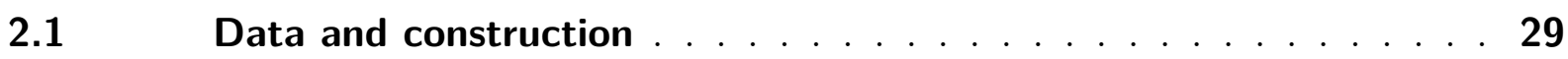

2.2 Descriptive statistics . . . . . . . . . . . . . . . . 31

$2.3 \quad$ Empirical strategy $\ldots \ldots \ldots \ldots \ldots$

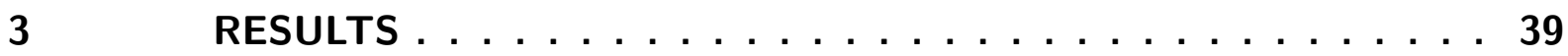

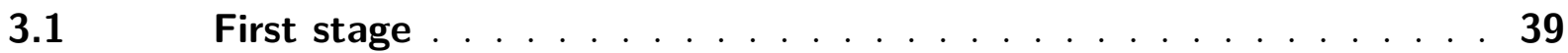

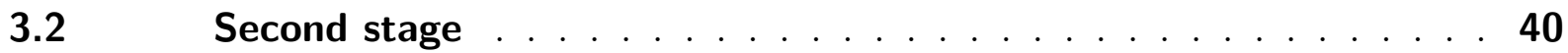

$3.3 \quad$ Additional results . . . . . . . . . . . . . . . . . 44

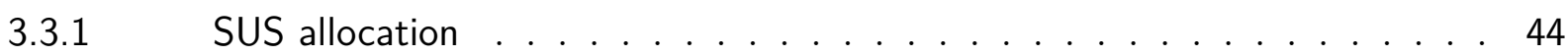

3.3.2 Lagged PM $10 \ldots \ldots \ldots \ldots 4 \ldots \ldots \ldots$

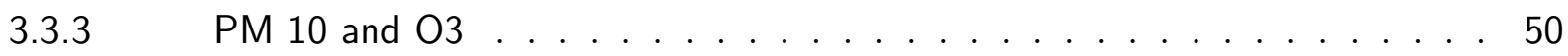

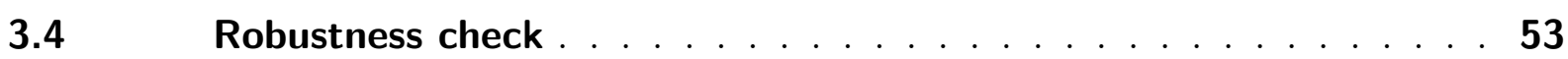

Concluding remarks $\ldots \ldots \ldots \ldots \ldots \ldots$

REFERENCE LIST $\ldots \ldots \ldots \ldots \ldots \ldots \ldots$

$\begin{array}{ll}\text { APPENDIX } & 63\end{array}$

APPENDIX A-FIRST STAGE $\ldots \ldots \ldots \ldots 6$

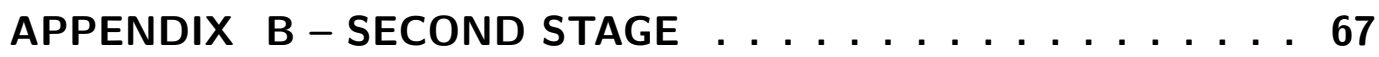

B.1 Main specification $\ldots \ldots \ldots \ldots \ldots \ldots \ldots \ldots$

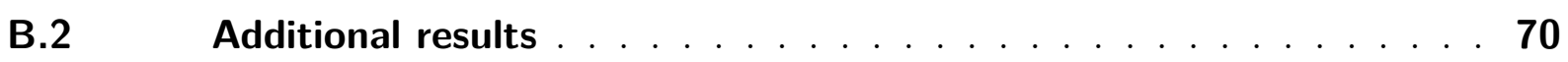





\section{Introduction}

There is evidence in the literature that air pollution negatively impacts health (CHAY; DOBKIN; GREENSTONE, 2003; CURRIE; NEIDELL, 2005; CURRIE; WALKER, 2011; SCHLENKER; WALKER, 2016; DESCHÊNES; GREENSTONE; SHAPIRO, 2017). Short-term exposure has been associated with increased respiratory illness and duration of symptoms, exacerbation of asthma and decline in lung function (POPE; DOCKERY; SCHWARTZ, 1995). Air pollution effects may differ between developed and undeveloped countries if we consider non-linear dose response between pollution and health, or if the costs of avoidance behavior are higher and the willingness to pay are lower in poorer country due to low income levels (ARCEO; HANNA; OLIVA, 2016; GREENSTONE; JACK, 2015). Another fact that may distinguish countries is the health infrastructure to meet health shocks, such as those related to poor air quality.

Figure 1 shows beds and physician per 1000 inhabitants for the main developing and developed countries, which are a measure of health infrastructure. The number of physicians in Brazil seems to be adequate, since it is above the World Health Organization (WHO) recommendation of one physician per 1000 inhabitant, although lower than in France and Germany. However, the number of hospital beds is only higher than in India. In that sense, response to health shocks via pollution can be intensified in developing countries, because it may overwhelm the health system, which either may prevent hospitalizations for other causes due to lack of infrastructure or just reschedule non-urgent procedures. Investigating if these countries have already adapted themselves to scarce resources or if this is not easily adaptable is still an open question in economic literature.

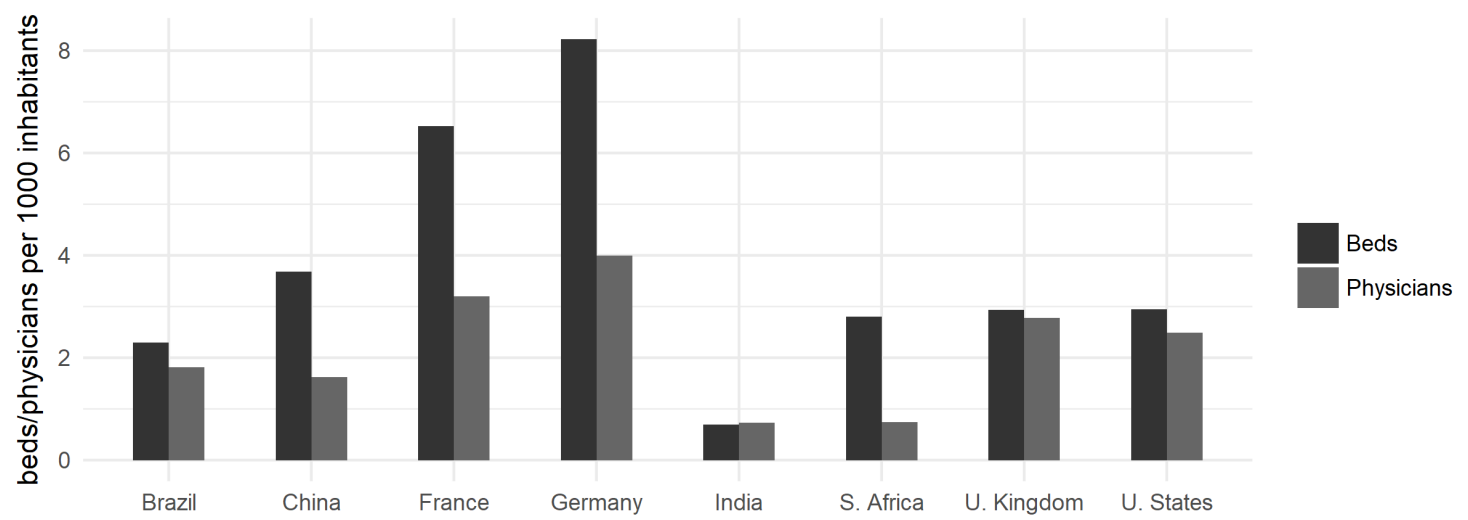

The graph shows the number of hospital beds and physicians per 1000 inhabitants. Values are the average for 2010 - 2012 (or available data between these years). For South Africa, the value is for 2005 (the last available). Source: World Health Organization.

Figure 1 - Hospital beds and physicians per 1000 inhabitants 
In order to measure the effects of pollution on health, we look at hospitalizations due to respiratory diseases for children in São Paulo Metropolitan Area (SPMA) between 2015 and 2017 as a consequence of variation in particulate matter of less than 10 micrometers aerodynamic diameter (PM 10) levels. SPMA is among the ten largest metropolitan regions in the world and the main urban agglomeration in South America. Among big cities, the level of PM 10 in SPMA is comparable to Mexico City and Istanbul, slightly less polluted than Johannesburg and much less polluted than Delhi and Beijing ${ }^{1}$. However, it is more polluted than London, Los Angeles and New York metropolitan areas as figure 2 shows. Although we look at recent data, we are close to developed countries decades ago, as well as China and India years ahead (HANLON; TIAN, 2015; CLAY; LEWIS; SEVERNINI, 2016).

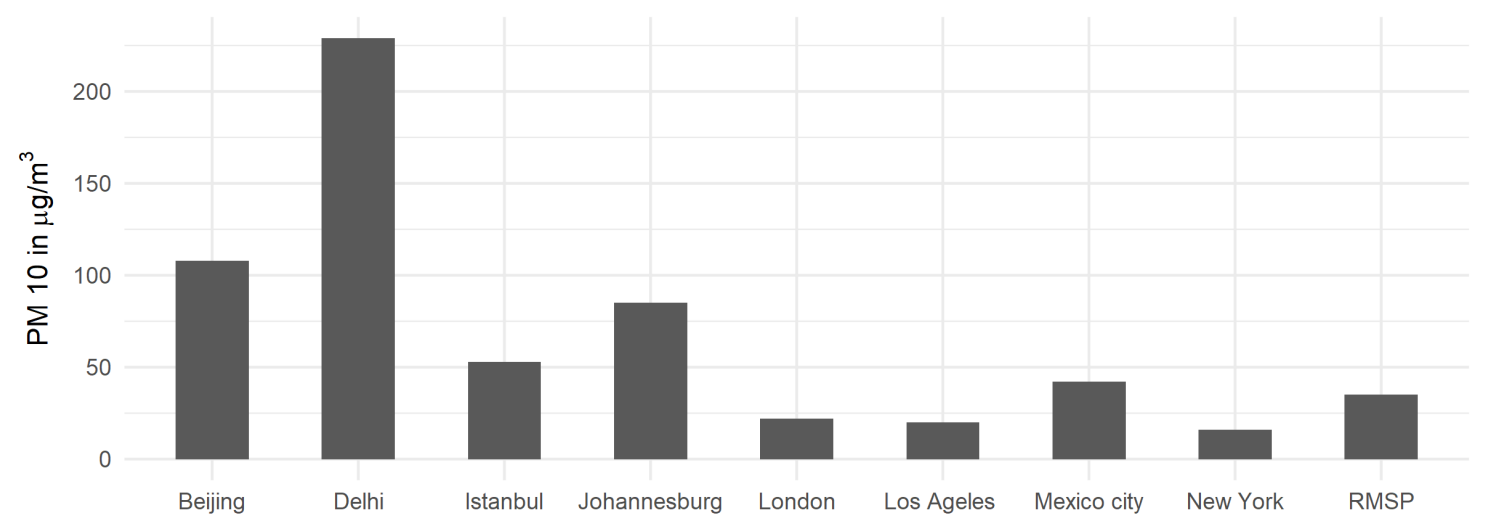

The graph shows the annual average of PM 10 for a few big cities in the world. New York and Los Angeles refer to the metropolitan region. Values are for 2014 (RMSP, Los Angeles, New York, Mexico City), 2013 (Beijing and London), 2012 (Istanbul) and 2011 (Johannesburg). Source: World Health Organization.

Figure $2-\mathrm{PM} 10$ in $\mu \mathrm{g} / \mathrm{m}^{3}$

The main sources of pollutants in SPMA are vehicles, following the pattern of urban areas in United States (CURRIE; WALKER, 2011). The endogeneity of air pollution exposure arises as a problem to investigate its effects on health since pollutants are not randomly assign to individuals as pointed by Dominici, Greenstone and Sunstein (2014). To deal with the endogeneity of air pollution, we had to find an instrument capable of dealing with non-stationary sources, and the wind speed performed well for this purpose. We disaggregate respiratory diseases into pneumonia, asthma and influenza, in order to check if the effects change between chronic and infectious diseases. As placebo outcomes, we use hospitalizations due to phimosis, hernia and appendicitis; the first two are predominantly schedule procedures, while the last is urgent. In a context of resources scarcity, diseases used as placebo can be interpreted as outcome variables when evaluating the impacts of air pollution on health. The ozone level is also pointed as a problem in SPMA (SALVO; GEIGER, 2014; CETESB, 2017), so we run a multi-pollutant model in addition, including

1 We are comparing levels for the whole metropolitan region of São Paulo with levels for Mexico City, Istanbul, Johannesburg, Delhi and Beijing without taking into account their metropolitan area. 
PM 10 and $\mathrm{O} 3$ as pollutant and adding solar radiation as instrument together with wind speed.

When it comes to pollution data, the Environmental Company of the State of São Paulo (CETESB) hourly tracks pollutants and meteorological variables for several monitors in SPMA ${ }^{2}$. This is the same data used by He, Gouveia and Salvo (2016) and Salvo and Geiger (2014). The health data are collected by SUS Hospitalization System (SIHSUS), which allow us to observe daily hospitalizations due to respiratory diseases and other causes by zip code of residence. We perform our estimates in two stages using districts in SPMA no further than 5 kilometer from any monitor as the unit of observation. We link these districts to the closest monitor and we calculate the hospitalization rate per one million of children for each day due to the diseases cited before as dependent variable. We also restrict our analysis for children below five years old since they have a more fragile health, more outdoor activities than other age groups, and their future outcomes can also be affected by consequences of contemporaneous bad air quality ${ }^{3}$ (CURRIE et al., 2014). Besides, air pollution exposure history for adults and elderly is difficult to determine.

Our first stage results point that wind speed is strongly correlated to PM 10, indicating that local air becomes cleaner as stronger the wind blows. Results for the second stage confirm that PM 10 is harmful for health, since hospitalization rate due to respiratory diseases increases as a result of positive variation in air pollution levels for children between one and five years old. We conclude that those hospitalization are shorter by verifying impacts on duration of hospitalization. Pneumonia and asthma admissions have the same behavior for this age group. On the other hand, only influenza admissions seem to be affected for infants, although our instrument may not be the ideal in this situation, since children under one have more indoor than outdoor activities. Estimates disregarding the endogeneity of air pollution underestimate the coefficients and robustness check confirms our results, suggesting that it is not driven by stationary sources of pollutants.

Going to additional results, we find that Brazilian public health system (SUS) is absorbing the increment of hospitalizations for respiratory disease and also for hernia and appendicitis, which are occurring in public hospitals. It is worth noting that we are not evaluating the quality of assistance and we are just checking spillover effects on a limited number of diseases. We also find that contemporaneous model underestimates our coefficients, since parents delay the visit to a doctor, although this delay does not seem to be long for children under one. Finally, regarding the multi-pollutant model, PM coefficients do not expressively change from the single pollutant model and we do not find

$\overline{2}$ CETESB measures some air pollution variables for a few monitors since 1972. Most pollutants and meteorological variables measurements started in 1981, but only after 2008 the monitoring became more expressive.

3 It may happen via contemporaneous outcomes, such as long-term effects of health problems, school absence, among others. Fletcher, Green and Neidell (2010) is an example for long-term impacts of childhood asthma. 
significant impact of ozone.

This study contributes to the literature by looking at health shocks driven by air pollution in a developing country, where pollutant levels are higher than in developed countries. Besides, we also investigate the allocation of an increased hospitalizations in the public system and potential reduction in other hospitalizations, since the number of beds in Brazil is below the recommended by WHO (between 3 and 5 beds per 1,000 inhabitants). We also run a multi-pollutant model, which has been considered a challenge in economic literature. Particulate matter and ozone co-variation, which may confound the effect in a single pollutant model, is discussed by Bell, Kim and Dominici (2007). Our results for PM 10 are robust to this co-variation, and we find no effect of ozone on hospitalization, although we do not rule out its impacts on health. The effects of this two pollutants are important to be investigated, once they are the main focus of the United States Environment Protection Agency (US EPA) and CETESB.

This paper also adds to the literature that investigates pollutants effects on developing countries, for example, Hanna and Oliva (2015) on labor supply in Mexico City and Jayachandran (2009) on early-life mortality in Indonesia; to literature that uses wind direction to explore exogenous variation in air pollutants (HERRNSTADT; MUEHLEGGER, 2015; DERYUGINA et al., 2016; ANDERSON, 2015); and to studies about the dynamics of pollutants in SPMA (SALVO; GEIGER, 2014; SALVO; WANG, 2017; SALVO et al., 2017).

This study is organized as follows: chapter 1 presents the background, discussing the problem of air pollution in SPMA, the operation of public health system in Brazil and epidemiological literature about effects of pollutants on human body. Next, in chapter 2 , we present data, descriptive statistics and identification strategy. In chapter 3, we show the main and additional results, and robustness check. Finally, we finish the study discussing our limitations and next steps. 


\section{Background}

\subsection{Why São Paulo Metropolitan Area?}

São Paulo Metropolitan Area (SPMA) is the largest metropolitan region in Brazil, where around 19.7 million people live according to 2010 Census $^{1,2}$, that is approximately $10 \%$ out of Brazilian population. Being among the 10 largest in the world, the region situated in southeastern Brazil consists of 39 municipalities, where the country's largest industrial zone is located. In Brazil, São Paulo Metropolitan Area is popularly known for traffic congestion and grey sky and, as most of large urban areas, the region also suffers for the bad air quality, high building density, too many people, lack of green areas and concrete surfaces.

The two main sources of pollution emission in SPMA are automobiles and industries ${ }^{3}$ (BRAGA et al., 2001a). Vehicular emissions are predominant in São Paulo, while industrial emissions are more relevant in municipalities of metropolitan area. According to CETESB (2016), more than 7 millions vehicles (among automobiles, trucks, buses and motorcycles) circulated in the region in 2015. Although São Paulo vehicular fleet is not old (8,9 years on average), CETESB (2016) draws attention to emission of pollutants, especially fine particulate matter and ozone levels, which usually reach the maximum reference values in SPMA.

Considering the sources of air pollution, the main emissions in SPMA are particulate matter(PM), nitrogen oxides (NOx), carbon dioxide $\left(\mathrm{CO}_{2}\right)$, and volatile organic compounds (VOC), most of them included in the group that needs frequently updating in air quality guidelines by WHO, given the constant evidence of effects on the human body even at low levels (WHO et al., 2015). The high emissions of NOx and VOC favor ozone formation, which is not directly emitted, but a secondary pollutant and an output from reaction involving NOx and VOC in sunlight presence (ORLANDO et al., 2010).

In the second half of the last century, the industrial activity was quite strong in São Paulo. While the city was growing, the industries migrated to the metropolitan region (BRAGA et al., 2001a). Due to the intense industrial activity and lack of environmental regulation, the air quality has deteriorated. As an example, a series of newspaper news pointed Cubatão (city in state of São Paulo close to SPMA) as the most polluted city in

1 São Paulo is the largest city in Brazil with a population of 11.2 million.

221 million according to estimates of the Brazilian Institute of Geography and Statistics (IBGE) for 2016.

3 It is important to note that Brazil obtains $70 \%$ of its electricity from hydroelectric power plants, reason why electric power generation is not an expressive source of air pollution, despite other environmental problems it generates (MIRANDA et al., 2012). 
the world in 1970s and 1980s ${ }^{4}$. Recently, industrial emissions are under control as the main economic activity changed from industries to service and trades. On the other hand, São Paulo grew up with poor public transportation planning, which together with government incentives for car purchases, resulted in a large number of private automobiles (BRAGA et al., 2001a; JACOBI et al., 1997). According to CETESB (2016), almost all hydrocarbon and carbon monoxide emission are emitted by vehicles, and about a half of particulate matter emission comes from mobile sources, mainly from black carbon ${ }^{5}$.

Around $85 \%$ of the fleet in SPMA consist of light-duty vehicles (LVDs) - cars, light trucks and sport-utility vehicles (SUV) (CETESB, 2016). CETESB (2016) points that around $60 \%$ of LDVs are flex-fuel, i.e., they are capable of running on either gasohol or ethanol $^{6}$. Although the last is known as a renewable fuel (biofuel), there is no consensus that flex-fuel with ethanol or ethanol-dedicated vehicles emit less polluters (NIVEN, 2005; COELHO et al., 2006) ${ }^{7}$, but it seems to reduce particulate matter emissions. On the other hand, gasoline and ethanol consumption is strongly associated to their prices, varying with economic cycles and government decisions.

As an effort to control emissions, the National Environmental Council (CONAMA) has created programs dedicated to control vehicular emissions ${ }^{8}$. Thanks to these programs, carbon monoxide is no longer a big concern in São Paulo Metropolitan Area ${ }^{9}$. Today, the state of São Paulo has the Plan for Reduction of Emissions from Stationary Sources - PREFE, created in 2014, which aims to map emissions by subregions of the state of

4 Since the 1990s, the air pollution in Cubatão is under control, as minimum regulations was imposed. However, particulate matter levels are usually close to the maximum established by the World Health Organization, who still considers the annual exposure to PM 2.5 well above the desired level.

5 According to United Stated Environmental Protection Agency (EPA), black carbon is the sooty black material emitted from sources that burn fossil fuel, in which a significant portion of particulate matter is found. In the case of vehicle emissions, heavy-duty vehicle is the most responsible.

6 It is a result of Brazilian Alcohol Program (Proalcool) in 1975, a government program to increase the production of alcohol given the rising in oil prices on the international market (COELHO et al., 2006).

7 Note that we are not considering emissions during fuel production. Just a quick explanation, there are a few oil refinery in SPMA, another source of air pollution. The state of São Paulo is the largest producer of sugarcane in Brazil, basic raw material for ethanol. The state has been suffering from sugarcane burning (common in sugarcane harvesting), however the fires are not close to SPMA.

8 The Air Pollution Control Programs for Motor Vehicles in 1986: PROCONVE for cars, trucks, buses and agricultural machinery and PROMOT for motorcycles and similar, setting gradually (in seven steps) deadlines, emission limits and establishing technological requirements for motor vehicles, domestic and imported. In 1989, CONAMA created the National Program for Control of Air Pollution (PRONAR), in order to establish limits for pollutants emission. PROCONVE was considered a path of action, as well as the National Program for the Control of Industrial Pollution (PRONACOP), National Air Quality Assessment Program, National Program for Inventory of Air Pollutants and State Air Pollution Control Programs. PRONACOP was created with the same idea as PROCONVE, but for industries. Since then, CONAMA has been updating the emission limits for static sources of pollution, tightening the control by discriminating fuel and sector limits, and requiring cleaner technologies. More details on CONAMA resolutions for static sources can be found in http://www.mma.gov.br/cidadessustentaveis/qualidade-do-ar/fontes-fixas.

9 CO was a big problem in SPMA before 1990s. In 1992, the government and automotive industry agreed to produce only vehicles with emissions-reducing devices, such as electronic fuel injection and catalysts (JACOBI et al., 1997). 
São Paulo. The city of São Paulo also has the Vehicle Pollution Control Plan - PCPV since 2011. Both programs aim to maintain emission levels within the requirements of CONAMA. The Environmental Company of the State of São Paulo (CETESB) ${ }^{10}$ was in charge of measuring the levels of pollutants in the air, leading to an expansion in measurements throughout the state. Nowadays, CETESB has monitors throughout the state of São Paulo ${ }^{11}$, in order to monitoring air pollution and meteorological variables.

\subsection{The Brazilian health system}

In Brazil, private and public health systems coexist, which include for-profit and non-profit institution, private health insurance sector and the Unified Health System (Sistema Único de Saúde (SUS)); the latter, which is known as the pubic health system, was established by the 1988 constitution $^{12}$ and its purpose is to assure free universal preventive and curative care (PAIM et al., 2011).

The private system can be complementary or supplementary to the public system. As complementary, purely private establishments provide services contracted by SUS, such as hospital beds and specific procedures. Besides purely private, philanthropic hospitals allocate at least $60 \%$ of their hospitals beds to SUS usage and, as a consequence, they are exempt from federal taxes. At first, SUS pays private and philanthropic hospital by procedures according to a procedure table prices $^{13}$, but they may agree additional values. The supplementary action is more direct, in which health centers only provide out-of-pocket hospital and ambulatory services and/or health plans and insurance.

Figure 3 presents hospital beds for hospitalization by bed location for the fourth largest metropolitan areas in Brazil and the total for all metropolitan areas. As smaller the number of beds in public hospitals, higher the share of beds located in philanthropic hospital, showing that their relationship is more complementary than supplementary.

Facing the challenge of providing good public heath to the entire population, SUS has been performing well in vaccination, high-cost services and complex procedures (such as haemodialysis and transplants), which are also used by private insured people according to Paim et al. (2011). SUS also manages the national HIV/AIDS prevention and control program and Popular Pharmacy Program (Programa Farmácia Popular), which provides subsidized medicines to treat the most common health conditions, such as diabetes, hypertension and asthma ${ }^{14}$. The creation of the Family Health Program (PSF)

\footnotetext{
10 CETESB made efforts to monitoring industries before CONAMA intervention, as well as to understand pollution sources in SPMA.

11 Most of them are located in SPMA.

12 This is the current constitution, created a few years after around two decades of military dictatorship.

13 These prices are normally below market prices.

14 This is an universal program.
} 


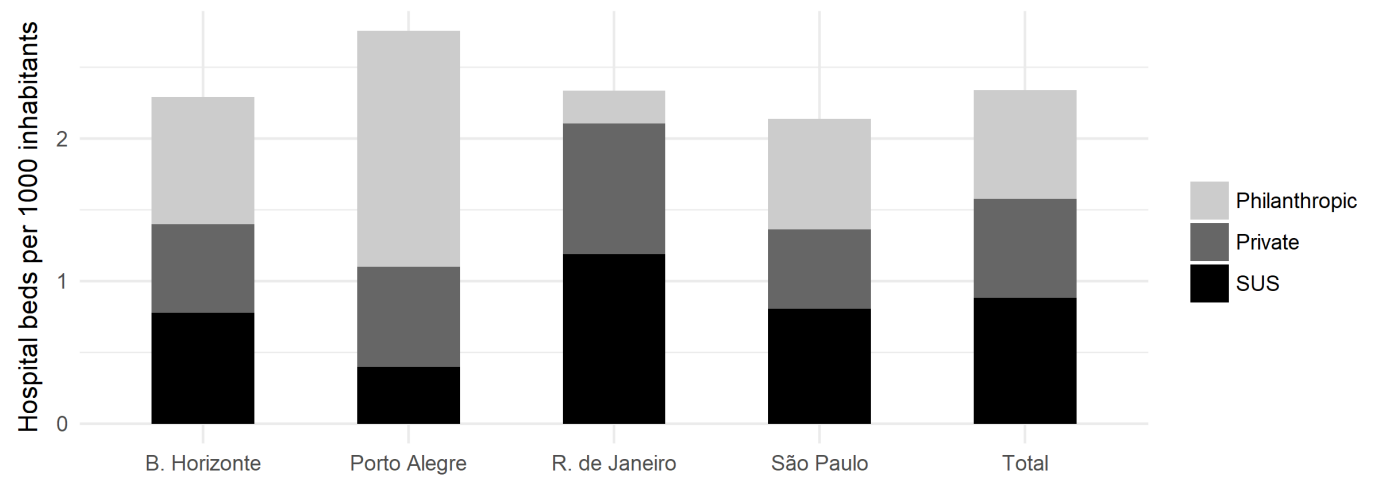

The graph shows number of hospital beds for hospitalization per 1000 inhabitants for the fourth largest metropolitan areas in Brazil and for all metropolitan areas separated by bed location: SUS/public hospitals, purely private hospitals and Philanthropic hospitals. Source: DATASUS.

Figure 3 - Hospital beds per 1000 inhabitants by bed location and metropolitan area

with the aim of decentralizing the health ${ }^{15}$ is also a SUS effort, which has been resulting in reduction of child mortality, complications from chronic diseases and hospitalization that could be threated with ambulatory procedures as discussed by Macinko and Harris (2015). SUS also manages other programs such as More Physician Program (Programa Mais Médicos), Psychosocial Care Network (Rede de Atenção Psicossocial) and Emergency Mobile Care Service (Serviço de Atendimento Móvel de Urgência (SAMU)).

Usually, SUS is formed not only by hospitals, but also by Basic Health Units (Unidade Básica de Saúde (UBS)) and Emergency Care Unit (Unidade de Pronto Atendimento (UPA)), where appointment and emergency of medium-high complexity are met respectively. The Prefecture of São Paulo points the city of São Paulo counts not only with those previously cited, but also with Ambulatory Medical Assistance (Assistência Médica Ambulatorial (AMA)) and Medical Specialist Ambulatory (Ambulatório Médico de Especialidades $(A M E))$ to meet the demand for procedures of medium complexity with the purpose of not overwhelming hospitals with cases that the patient's life is not at risk $^{16}$. We cannot find AMA and AME out of the city of São Paulo. The Prefecture of São Paulo also points that public facilities (especially Basic Health Unit) are better distributed throughout SP than private ones, although hospitals are concentrated in the center of the city (ATLAS..., 2011).

Back to figure 3, São Paulo Metropolitan Area has less beds for hospitalization than the average of all metropolitan areas. On the one hand, we may think the health structure available is not enough to meet São Paulo Metropolitan Area demand for health assistance; besides that, the number of hospital beds is lower than the recommended by WHO for all regions in the figure. On the other hand, we may think the reduction in

\footnotetext{
15 The purpose of the program is providing primary health care and keep regular visit to the household, in order to reduce hospital demand, and take care of those who do not have easy access to hospitals.

16 None of them has hospitals have hospital beds for hospitalization.
} 
the number of beds is a natural consequence of an improvement in provision of primary health services, which may either reduce the demand for health assistance in general or the demand for high complex services, since basic assistance can be more easily found.

\subsection{Air pollution and human health}

WHO et al. (2015) not just update the Global Air Quality Guidelines (AQGs), but discuss experts opinions on the latest evidence of health impacts for several air polluters ${ }^{17}$. In general, WHO draws attention to the short-term effects, which have proved quite significant, though fragile, while the long-term effects seem to be more robust. In addition, polluters have been shown to affect health even in low levels. For classical pollutants $\left(\mathrm{NO}_{2}, \mathrm{O}_{3}, \mathrm{PM}\right.$ and $\left.\mathrm{SO}_{2}\right)$, WHO argues that evidences of their effects on health became larger after 2006. Most studies find impacts on respiratory and cardiovascular system in short- and long-term, lung functions, lung carcinogenicity and mortality in the long-term, although it points to the need to look at other health endpoints.

The medical literature has investigated more expressively the impacts of particulate matter (POPE, 1989; POPE, 2000; BRAUER ANDREW CHURG, 2000; BRAGA et al., 2001a), specially the smaller ones. These particles are a result of combustion from mobile or stationary sources, very common in urban centers, and can easily penetrate the tissues of the body, as well as increase blood coagulation, which can cause heart attacks and lung problems (BRAUER ANDREW CHURG, 2000; BRAGA et al., 2001a). Furthermore, constant exposure to high amounts of particulate matter in the air, more common in heavily polluted cities, also increases the chance of developing chronic obstruction of airways (CHURG et al., 2003). Braga et al. (2001a) argue that studies have found harmful health effects even when the amount of pollutants is bellow the legally permitted levels, reason why the upper limit needs continuous update.

Besides influencing chronic, chronic obstructive pulmonary disease and allergic rhinitis hospitalizations, epidemiological studies have linked air pollution with respiratory infection diseases, such as influenza and pneumonia, once pollutants reach natural defenses of the lung (KELLY; FUSSELL, 2011). Furthermore, Zelikoff et al. (2002) highlight a worsening of pneumonia in individuals exposed to particulate matter, beyond undermining pulmonary immune response, suggesting that pollutants can both facilitate and worsen infectious diseases. Risk for and severity of respiratory tract viral infection are also pointed by toxicology literature (SARAVIA et al., 2013).

Pollutants do not reach the organisms equally. Children and elderly are more likely to suffer from bad air quality, once they have a more susceptible immunological system, while people with chronic disease, such as asthma, may have more acute episodes

17 Those are results of a global consultation meeting organized by WHO, held in September 2015. 
(GOUVEIA; FLETCHER, 2000b; BRAGA et al., 2001b). In the long-term, the life expectancy of inhabitants of more polluted environments significantly decreases (POPE, 2000). For children, we should also take into consideration that both short- and long-term outcomes can be affected by pollution exposure (CURRIE et al., 2014).

Kampa and Castanas (2008) discuss studies that associate different polluters to diseases, concluding that all pollutants may impact the airways. Despite all efforts to determine the effects of each pollutant on health, WHO et al. (2015) discuss the challenge of isolating these effects, since, in most cases, they are emitted simultaneously from the same source, and different sources emit same pollutants. The existence of confounding effects due to high correlation between pollutants is also discusses by (BELL; KIM; DOMINICI, 2007). 


\section{Methodology}

\subsection{Data and construction}

Health data are disclosed by DATASUS, specifically by the SUS Hospitalization System (SIHSUS), an administrative data of Brazilian public health system (Health Unified System - SUS). We observe data for all admissions by individuals' zip code of residence, including date of admission, duration, hospitalization expenditure and diagnosis according to the International Statistical Classification of Disease and Related Health Problems Tenth Revision (ICD-10) ${ }^{1}$. The majority of admissions in Brazil are funded by SUS ${ }^{2}$.

We restrict the dataset for children under five years old who were living in the Metropolitan Area of São Paulo ${ }^{3}$. We also split the data into two groups: younger than one and between one and five years old. We decide to not work with other age groups because pollution effects on adults and elderly should be cautiously interpreted since we do not know their exposure history and adults usually spend their time working, making it difficult to decide which pollution exposure is more realistic, the one measured near home or near work. Furthermore, children usually have more outdoor activities and, therefore, higher air pollution exposure. Besides that, health problems at this age may have long term effects (CURRIE et al., 2014; FLETCHER; GREEN; NEIDELL, 2010).

Air pollution and weather variables are collected by Environmental Company of the State of São Paulo (CETESB) since 1972 by few monitors at the beginning. Today, data are hourly measured by 30 monitors throughout $\mathrm{SPMA}^{4}$, although not all variables are measured by all monitors. The analysis is restricted to particulate matter with less than 10 micrometers diameter (PM 10), in $\mu \mathrm{g} / \mathrm{m}^{3}$, motivated by the high level of this pollutant in $\mathrm{SPMA}^{5}$. The weather variables used are humidity, in percentage, temperature, in degree Celsius, wind speed, in $\mathrm{m} / \mathrm{s}$, and global solar radiation, in $W / \mathrm{m}^{2}$.

1 Inside respiratory hospitalizations, we consider admissions due to respiratory diseases, such as pneumonia, bronchitis, allergic rhinitis, asthma, pneumoconiosis due to inorganic dust, respiratory disease due to inhalation of chemical, gases, fumes and vapors, respiratory insufficiency, among others, according to the International Statistical Classification of Disease and Related Health Problems - Tenth Revision (ICD-10).

213.5 million admissions occurred in Brazil in 2016, of which around 11.7 millions were founded by SUS. Source: DATASUS. This number is probably lower in southwestern region, where health plans and insurance market is higher (PAIM et al., 2011).

3 Hospital admissions were processed between the beginning of 2015 until February 2018. DATASUS hospitalizations data are grouped by month of processing, which may differ from month of hospitalization.

4 Pollutants measured are: $M P_{10}, M P_{2,5}, S O_{2}, \mathrm{NO}, N_{2}, N O_{X}, C O$ and $O_{3}$, plus a few volatile organic compounds. Meteorological variables measured are: humidity, temperature, wind speed, wind direction, air pressure and solar radiation.

5 PM 2.5 is not used due to data constraints, however particulate matter with less than 2.5 micrometer diameter is also considered in PM 10 measurement. 
In order to construct our dataset on a daily basis, a few steps are taken. First, we turn into missing all days with information for less the twelve hours. Next, for the non-missing days, we fill the variable informations of missing hours by weighting the first hour before and after by $1-\frac{\left|h_{i}-h_{m}\right|}{h_{a}-h_{b}} \mathrm{i}=\mathrm{a}, \mathrm{b}$, in which $h_{a}$ is the hour after, $h_{b}$ is the hour before and $h_{m}$ is the missing hour ${ }^{6,7}$. Finally, we take the daily average. For the missing days, we follow the same weighted average procedure described before, but for days instead of hours ${ }^{8}$.

With the purpose of not wasting pollution information and considering that not all monitors measure all variables, we spatially interpolate only meteorological variables, in order to have complete weather information for all monitors that measure some pollutant, using the inverse of distance as the criteria ${ }^{9}$. The decision of not spatially interpolating pollution data comes from the non-randomness of measurement sites, as discussed by Muller and Ruud (2018), once there are maximum levels established for pollutants concentration, which is not true for weather informations, and CETESB is an environmental inspection agency. Due to missing informations for pollutants, our panel is not balanced.

Back to health data, to take advantage of individuals geographical location without interpolating pollution data, we link the individual to the district of SPMA where the zip code of his residence is located, and then the pollution and weather information assigned to the district is the one measured in the closest monitor, limiting to the districts whose centroid is not further than 5 kilometers from the monitor and those that have a monitor inside as figure 4 shows - this exercise is also done for other radius as robustness. In this sense, we calculate the hospitalization rate per one million children and the duration of hospitalization (in days) in each district every day. To construct hospitalization rate, we use the population counted in Census-2010 ${ }^{10}$, geo-referenced in SPMA by Center of Metropolitan Studies (CEM), only considering the age group in analysis. After all restrictions, our dataset counts with 28 monitors $^{11}$.

$\overline{6}$ For missing hours in the beginning and/or in the end of the day, we repeat the next and/or last information respectively.

7 For example, if we have no information for 3PM and 4PM, but we do for 2PM and 5PM. We fill the value for $3 \mathrm{PM}$ weighting informations for $2 \mathrm{PM}$ by $\frac{2}{3}$ and for $5 \mathrm{PM}$ by $\frac{1}{3}$. On the same way, we weight $2 \mathrm{PM}$ by $\frac{1}{3}$ and $5 \mathrm{PM}$ by $\frac{2}{3}$ to fill the values of $4 \mathrm{PM}$.

8 This procedure is done year by year. A difference to the hour procedure is that if there is no measurement before and after, we keep the missing.

9 This criteria has already been used for similar purposes, see Neidell (2004) and Schlenker and Walker (2016).

10 Census is conducted by the Brazilian Institute of Geography and Statistic (IBGE) every 10 years. Beyond counting the population, Census also provides socio-economic and other demography informations about Brazil.

1128 monitors measure PM 10 or O3. 23 monitors measure PM 10 and 23 measure O3. 


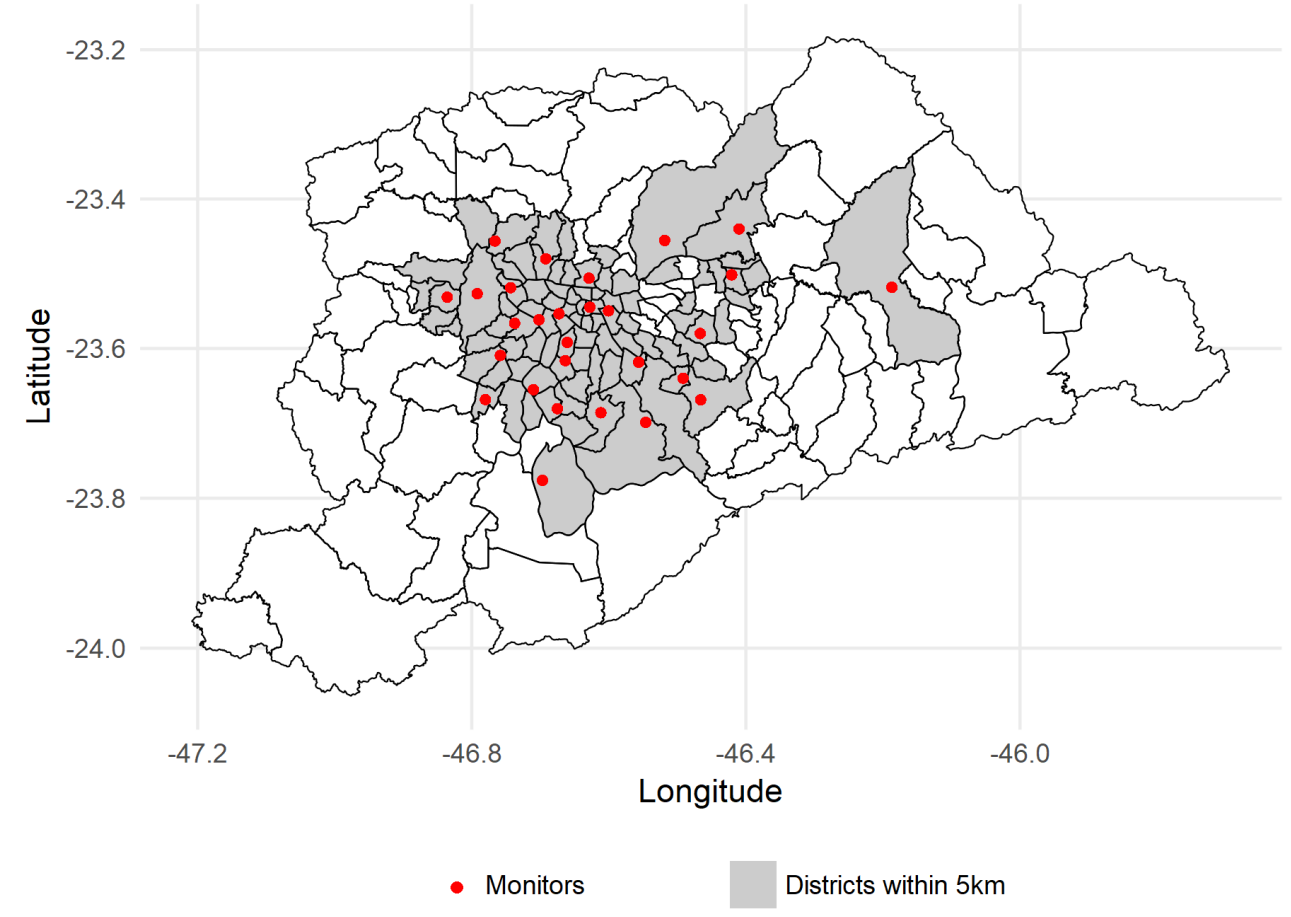

The figure shows monitors location (red points) and districts no further than $5 \mathrm{~km}$ or housing a monitor (grey polygons).

Figure 4 - Monitors and districts within $5 \mathrm{~km}$

\subsection{Descriptive statistics}

Figures 5 and 6 show the daily mean and maximum level of PM 10 and O3 respectively by monitor. The small numbers above the red line represent the number of days with average concentration above World Health Organization (WHO) short term guidelines between 2015 and 2017 - 24 hours for PM 10 and 8h daily for O3 ${ }^{12}$ (guidelines are defined in WHO et al. (2015)).

WHO establishes maximum PM concentration for a day (short-term exposure) dashed line - and for the average of a year (long term exposure) - solid line. PM levels draw attention since it is above the recommendation for almost all monitors. For O3, the annual average does not give us too much information since there is no long term guideline established by WHO. O3 levels are usually above WHO sort term guideline, although it seems that PM 10 reaches the maximum acceptable level more often than O3. Moreover, even though we can see correlation between PM 10 and O3, we can also point monitors that usually have measurements beyond the cutoff for PM, but not for O3 and vice versa, such as Carapicuíba, Guarulhos, Diadema, Interlagos, among others.

Monitors location and hospitalization rate for respiratory disease by quartile can be seen together in the figure 7 by district, only for the districts no further than $5 \mathrm{~km}$. Numbers on the map represent the number of the monitors - number together with the

$\overline{12}$ We take the average from 9AM to 5PM. 


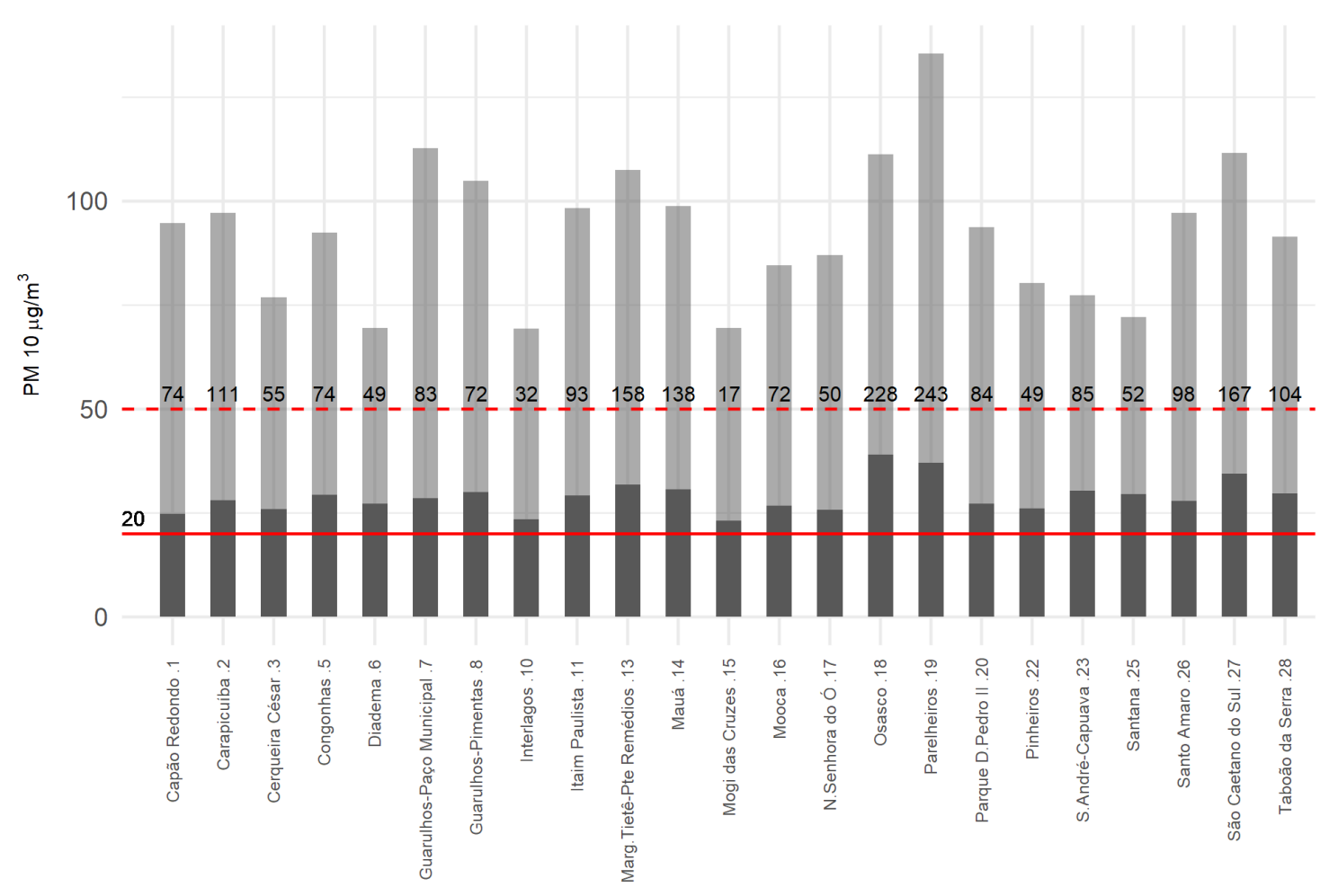

The graph shows the annual average (dark gray) and maximum daily average (light gray) of PM levels. Lines indicate the values recommended by WHO: red dashed line represents the daily maximum for PM 10, solid line represents the maximum annual average. Numbers above dashed line show number of days above the maximum recommended by monitor between 2015 and 2017.

Figure 5 - Average and maximum PM, and number of days above WHO guidelines

name in figures 5 and $6^{13}$. As darker the district is, higher the hospitalization rate. The relationship between hospitalization rate and air pollution is not directly seen in the map, although we can see that almost all districts in the western border belong to third or fourth quartile. One of the two biggest airports in SPMA is located near monitor 6 and the other is set between monitors 7 and 8 . Since the main sources of pollutants are the vehicles, figure 8 shows expressways and highways in SPMA. Besides that, we can also find a lot of large avenues, which would make the map unreadable if plotted.

SPMA has more than one central business district (CDB) and public transportation is planned to link those places to predominantly residential areas. CDBs are located in the most central regions of the city, where the costs of living are higher. Usually, families with high income can afford living in these areas, who may also have better health and afford a healthy growth to their children. Although, it is common finding poor neighborhoods and favelas $^{14}$ around rich neighborhoods. This context suggests why almost $70 \%$ of children population live in the districts considered in this study.

Table 1 summarizes daily hospitalizations for respiratory diseases for children under

13 The charts only have monitors that measure the respective pollutant, while the map has all monitors.

14 Brazilian informal and low income urban areas. 


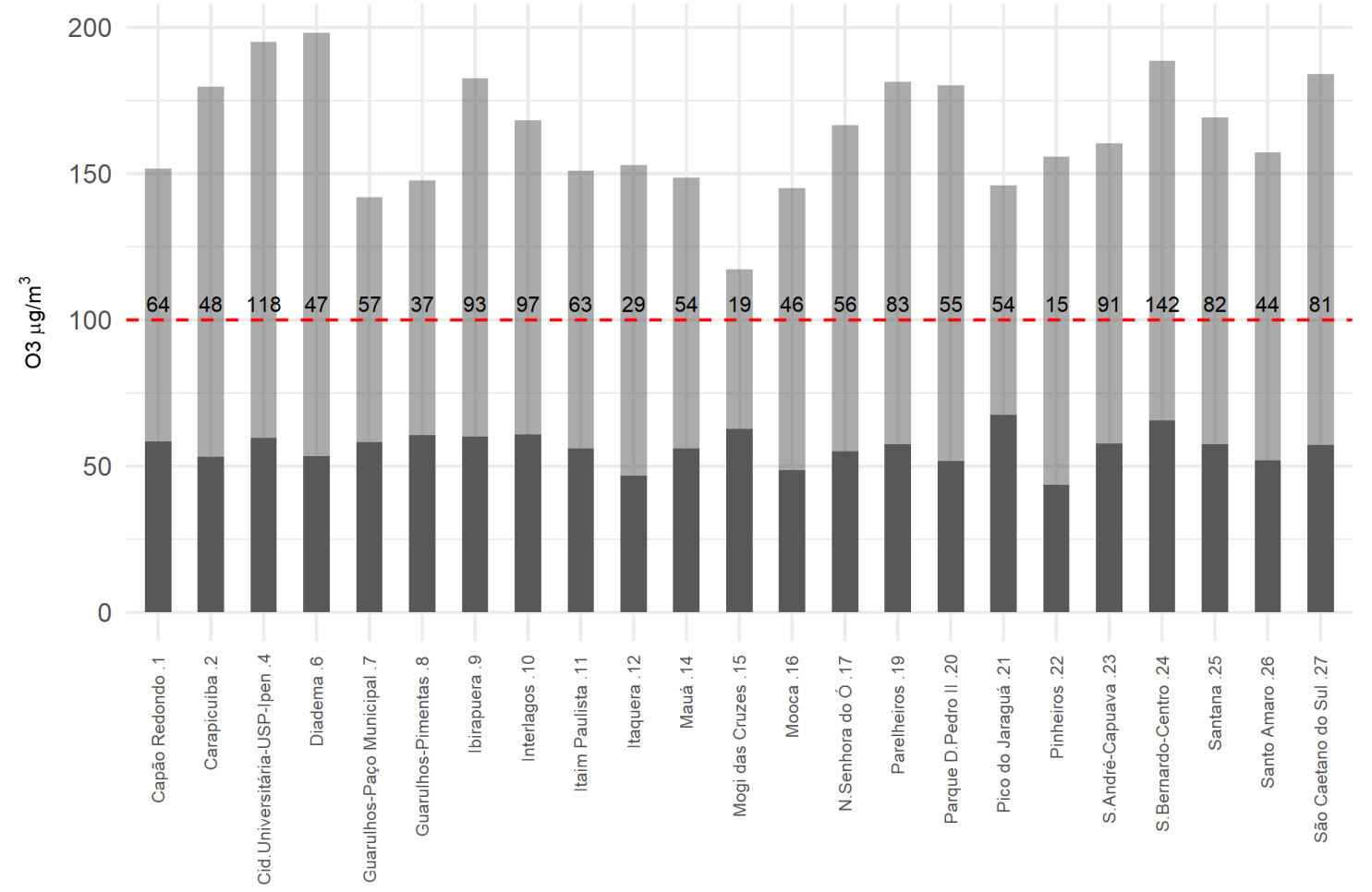

The graph shows the annual 8h-average (dark gray), maximum 8h-average (light gray) and number of days above the maximum (numbers above dashed red line) by monitor between 2015 and 2017. We use the values recommended by WHO: the red line represents the maximum $8 \mathrm{~h}$ daily for O3. We use measurements from 9AM to 5PM to construct the daily (8h-average) measurement.

Figure 6 - Average and maximum O3, and number of days above WHO guidelines

5 years old, PM 10 and O3 concentrations, and average wind speed by year. We cannot see any expressive change between years. For both admissions and pollutants concentrations, we can see a strong difference between maximum and mean values, reflecting the temporal variation and existence of peaks in pollution. The total admission represents around 35\% of all children (ages 0-5) hospitalizations afforded by SUS in the city of São Paulo, and $12 \%$ of those occurred in the state of São Paulo.

Table 1 - General characteristics by year

\begin{tabular}{c|c|c|c|c|c|c|c|c|c}
\hline & \multicolumn{3}{|c|}{ daily hospitalizations } & \multicolumn{2}{c|}{ PM 10 } & \multicolumn{2}{c|}{ O3 } & \\
\hline Year & mean & maximum & total & $\begin{array}{c}\text { average } \\
\text { rate }\end{array}$ & mean & maximum & mean & maximum & wind speed \\
\hline 2015 & 0.72 & 18 & 24,372 & 48.82 & 31.02 & 120.58 & 36.08 & 109.07 & 1.76 \\
2016 & 0.68 & 18 & 25,754 & 48.71 & 29.69 & 135.5 & 36.15 & 91.96 & 1.81 \\
2017 & 0.74 & 17 & 27,602 & 50.05 & 29.19 & 128.21 & 39.13 & 125.04 & 2.02 \\
\hline
\end{tabular}

Table brings mean, maximum, total and average rate of daily hospitalizations, as well as mean and maximum concentration for PM 10 and $\mathrm{O} 3$, in $\mu \mathrm{g} / \mathrm{m}^{3}$, and average wind speed, in $\mathrm{m} / \mathrm{s}$, by year. For hospitalizations, we only count districts within 5 $\mathrm{km}$ around monitors.

In general, the majority of respiratory hospitalizations for children under five years old are short as the histogram in the figure 9 shows. Besides that, pneumonia hospitalizations represent around $46.43 \%$ of all respiratory admissions, being the disease with 


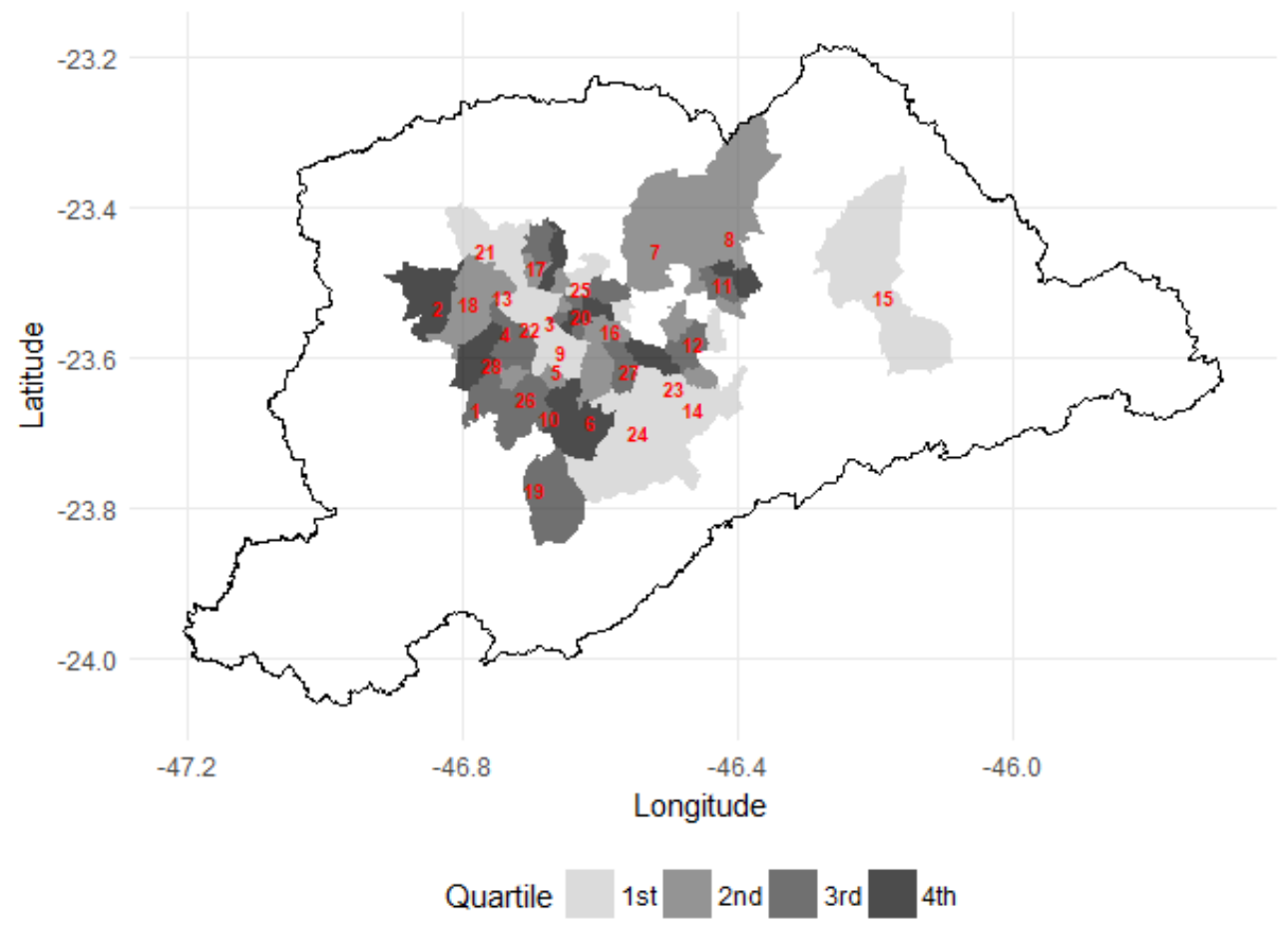

The map shows the average hospitalization between 2015 and 2017 by quartile. The red number represents the number of the monitor pointed in charts 5 and 6 .

Figure 7 - Hospitalization rate and monitors location

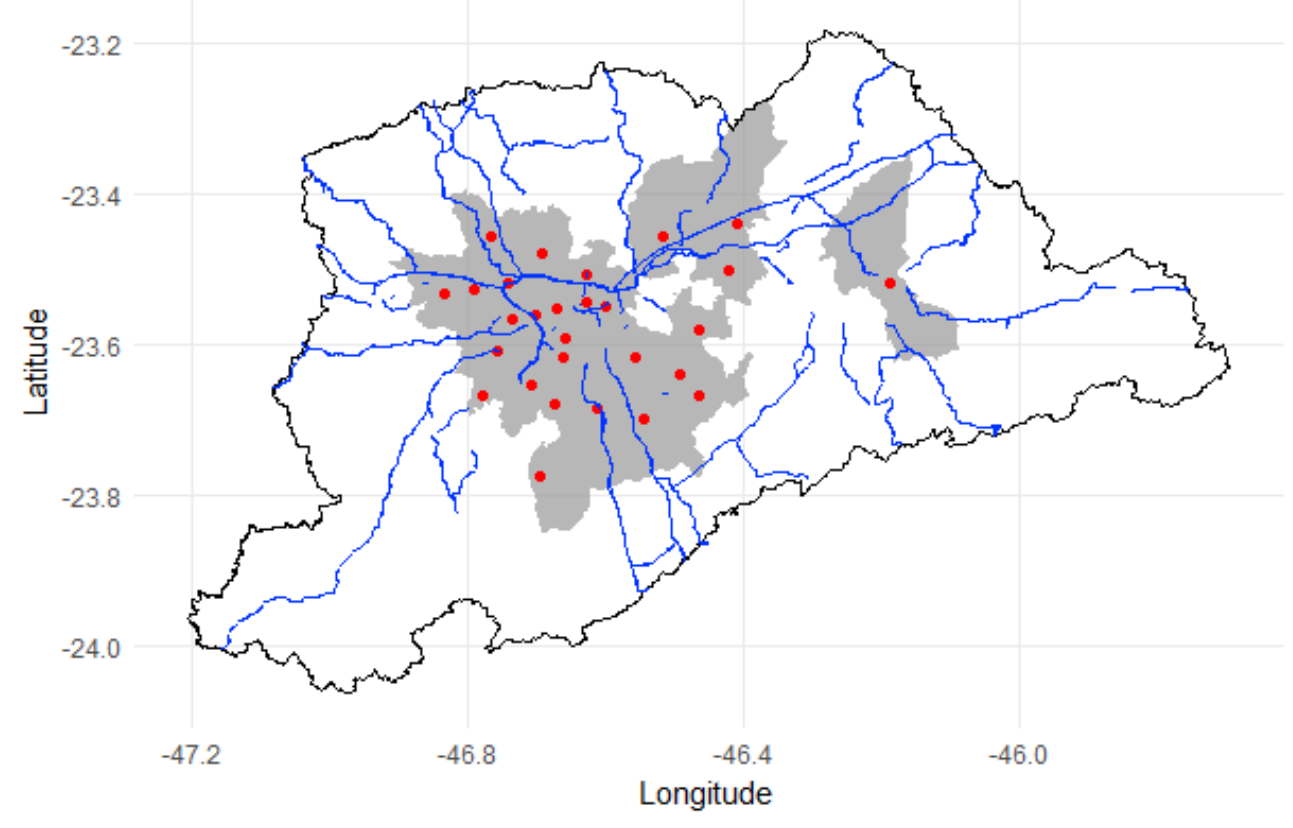

- Monitors

Districts within $5 \mathrm{~km}$

The map shows expressways and highways together with monitors and districts within $5 \mathrm{~km}$.

Figure 8 - Expressways and highways 


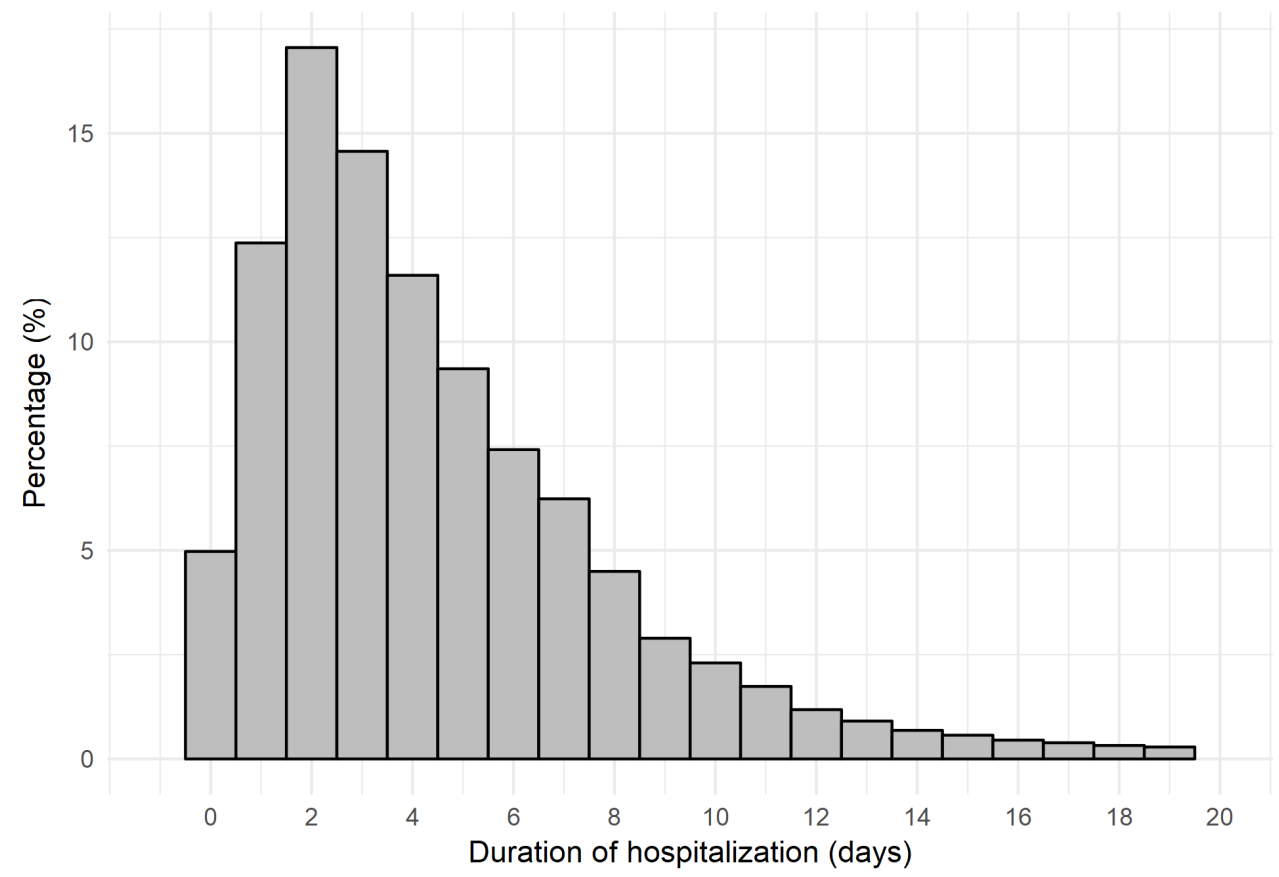

Figure shows the histogram of the duration of hospitalizations. We only plot durations up to 20 days, since just a few admissions last more than 20 days.

Figure 9 - Duration of hospitalization histogram

the highest share. Asthma, quite known as respiratory chronic disease, represents around $8.18 \%$ of the total. We also check effects on influenza hospitalizations, however this kind of admission is not common, representing only $0.26 \%$ of total respiratory admissions. Influenza hospitalizations have an odd behavior, since the region experienced an influenza epidemic in 2016, counting more hospitalizations than 2015 and 2017 together. Besides, Brazilian government promotes influenza vaccination campaign every year before the beginning of winter (June in southern hemisphere), on what children, elderly and pregnant women are the priority group ${ }^{15}$.

\subsection{Empirical strategy}

Evaluating the impacts of air pollution on health is not a simple task since endogeneity from different sources may arise. First of all, pollutants are not randomly assigned across locations and we do not precisely know the pollution exposure of each individual. Most literature assumes that individuals do not observe air quality and, consequently, do no react to air pollution levels. Despite the simplicity of this assumption, Neidell (2004) discusses that individuals might avoid activities that expose them to air pollution, in order

15 Influenza vaccines are free of charge and the entire population can be vaccinated after attending the priority group. Despite the vaccines availability, government does not always reach the vaccination targets for the priority groups. 
to reduce negative externalities, and estimates disregarding this avoidance behavior would be a lower bound of air pollution impacts on health.

Another potential source of endogenenity due to unobserved variables is the level of economic activity, which is positively correlated with air pollution, causing a negative bias on the impact on health by the income increase, for example Hanna and Oliva (2015) and Herrnstadt and Muehlegger (2015). It is also worth noting that the level of economic activity may influence the avoidance behavior. Lastly, our estimates by proxying the exposure by the closest monitoring data would lead us to an unavoidable measurement error, which would attenuate our estimates if we consider this error as a Classical Error in Variables $(\mathrm{CEV})^{16}$.

We use an instrumental variable approach to deal with potential sources of endogeneity. As vehicles are the main sources of air pollution in SPMA and we can observe many roadways in the region, beyond expressways and streets that can be heavily congested in peak times, we need an instrument capable of dealing with non-stationary sources of pollution. In that sense, we use the wind speed as instrument for air pollution. The wind has become important in recent studies about air pollution (ALLEN et al., 2013; DERYUGINA et al., 2016; HERRNSTADT; MUEHLEGGER, 2015; SCHLENKER; WALKER, 2016). Seaman (2000) argues that wind is a key meteorological variable as it directly influences the distribution and horizontal transport of air pollutants and vertical dispersion in a region.

We perform the estimates in two stages. First, we regress air pollution levels on wind speed. Second, we regress health outcomes on the air pollution predicted in the first stage. With the purpose of better capturing an exogenous part of particulate matter and taking advantage of pollutant persistence on time, we run an overidentified model with the wind speed on the day of admission and one day before as instruments. Regressions are controlled by temperature, temperature ${ }^{2}$, humidity, humidity ${ }^{2}$ and temperature*humidity. The exact specification is:

$$
\begin{gathered}
P M_{i t}=\alpha+\beta_{1} w s_{i t}+\beta_{2} w s_{i t-1}+\pi \text { controls }_{i t}+\theta_{i}+\mu_{t}+\epsilon_{i t} \quad \text { (1st stage) } \\
\text { health }_{i t}=\gamma+\lambda_{1} P \hat{M}_{i t}+\sigma \text { controls }_{i t}+\eta_{i}+\delta_{t}+\varepsilon_{i t} \text { (2nd stage) }
\end{gathered}
$$

Where i denotes the district and the days along 2015, 2016 and 2017. PM is the level of particulate matter with less than 10 micrometer diameter. We run this specification for three different groups: children aged between zero and five, children between one and five and children below one year old. Our preferred specification is for districts no further than 5 kilometers from monitors, but we run the main specification for other cutoffs in appendix.

16 This error will be present even if we consider other ways of proxying pollution data, such as interpolation. 
We also include fixed effects, in order to capture time-invariant characteristics of districts, such as socioeconomic status and geography of the region, so we explore variation within districts. Furthermore, any urban condition that may change wind speed, such as high buildings, is controlled by district fixed effects, unless it has changed between 2015 and 2017. In order to correct seasonality problems that could confound with pollution effects, we add to the model month and day of the week dummies.

As health outcomes, we use hospitalization rate and duration of hospitalization for respiratory diseases according to ICD-10. We also check the effects on specific diseases such as asthma, pneumonia and influenza - all included in respiratory - which is an opportunity to investigate the pollutants effects on chronic and infectious diseases (the second is predominantly bacterial and the third predominantly viral disease $)^{17}$.

Since we include year fixed effects, the influenza epidemic in 2016 is controlled if we consider a homogeneous incidence in SPMA. Considering vaccines campaign, a possible occurrence of herd immunity is a limitation for estimating impacts of air pollution on influenza hospitalizations, but probably not on hospitalization due to all respiratory because the number of influenza admission is low as we discussed in the previous section. There is also free vaccine for bacterial pneumonia in Brazil, but it is not recommended for children under 2 years old and the priority groups are elderly and individuals above two with predisposing conditions to recurrent pneumococcal infections. Besides, this vaccine does not protect for all types of pneumonia and the effectiveness is not $100 \%$. So, we believe vaccines are not a major concern.

As additional results, we check effects of PM 10 on phimosis, umbilical and inguinal hernia and appendicitis. The first two are predominantly schedule hospitalization, while the second is urgent. If we believe that hospitals face bed restrictions, these variables are outcome variables rather than placebos. So, this is an opportunity to investigate public hospital overwhelming. We also verify cumulative impacts of pollutants and/or displacement on hospitalization date ${ }^{18}$. Lastly, we run a multi-pollutant model with PM 10 and $\mathrm{O} 3$ as pollutants, including solar radiation as instrument, in order to get a ceteris paribus variation for each pollutant.

In order that the second stage gives us the causal effect of air pollution on health, we need the following identification hypothesis: $E\left(P M_{i t} * \varepsilon_{i t} \mid \eta_{i}\right.$, controls $\left._{i t}\right)=0$, i.e., given fixed effects and controls, the wind speed only affects health outcomes through PM 10 variation. A valid first stage is required before discussing the identification hypothesis.

\footnotetext{
17 The ICD code used for pneumonia is "pneumonia by unspecified microorganism", which is the most recurrent code for pneumonia.

18 See Schlenker and Walker (2016) for better discussion.
} 



\section{Results}

This chapter presents one section for first stage, second stage, additional results and robustness check. At first, all results consider the specification presented in empirical strategy for districts no further than 5 kilometers. All regressions include fixed effects of districts, day of the week, month and year, and they are controlled by temperature, temperature $^{2}$, humidity, humidity ${ }^{2}$ and temprerature $*$ humidity. They are also two-way clustered by district and day levels and weighted by districts' population. Particulate matter measurement is given by $10 \mu \mathrm{g} / \mathrm{m}^{3}$.

\subsection{First stage}

Table 9 shows first stage results: regression of PM 10 on wind speed. The results are different between age groups because regressions are weighted by its respective population. Coefficients of wind speed on the day and one day before admission are expected to be negative. The idea is simple: the wind carries pollution, so the stronger the wind blows, the more air pollution is taken away, leaving the local air cleaner, and it is exactly what we find.

Table 2 - First stage

\begin{tabular}{|c|c|c|c|}
\hline & Ages 0-5 & Ages 1-5 & Ages 0-1 \\
\hline & $P M_{t}$ & $P M_{t}$ & $P M_{t}$ \\
\hline$w s_{t}$ & $\begin{array}{c}-0.662^{* * *} \\
(0.0563)\end{array}$ & $\begin{array}{c}-0.662^{* * *} \\
(0.0564)\end{array}$ & $\begin{array}{c}-0.662^{* * *} \\
(0.0563)\end{array}$ \\
\hline$w s_{t-1}$ & $\begin{array}{c}-0.187^{* * *} \\
(0.0469)\end{array}$ & $\begin{array}{c}-0.187^{* * *} \\
(0.0469)\end{array}$ & $\begin{array}{c}-0.187^{* * *} \\
(0.0468)\end{array}$ \\
\hline F-statistic & 82.54 & 82.45 & 82.98 \\
\hline Number of districts & 77 & 77 & 77 \\
\hline Number of days & 1,096 & 1,096 & 1,096 \\
\hline Observations & 78,956 & 78,956 & 78,956 \\
\hline
\end{tabular}

Table shows the results of first stage: regression of PM 10 on contemporaneous and lagged wind speed. Columns represent regressions for different groups (weights). F-statistics refer to the test of joint significance of instruments. Standard errors in parentheses are twoway clustered by district and day. To check significance: ${ }^{* * *} \mathrm{p}<0.01$, ** $\mathrm{p}<0.05,{ }^{*} \mathrm{p}<0.1$.

As the first stage aims to investigate the correlation between the endogenous variable (PM 10) and instruments, we need to check how strong this correlation is. So, we report the F-statistics of join significance of instruments, which are always higher 
than 10 (a benchmark pointed by literature as discussed by Stock and Yogo (2005)), suggesting that instruments are strong. It is also worth noting that wind speed on the day before admission has a lower impact on contemporaneous air pollution comparing to the impact of contemporaneous wind. In robustness check session, we better explore this time sensitiveness.

In appendix A, we show first stage results considering different cutoffs for the distance between districts and monitors; we test for $3 \mathrm{~km}, 7 \mathrm{~km}$ and $10 \mathrm{~km}$. Since we are just adding (or dropping) districts linked to a monitor already used in $5 \mathrm{~km}$ cutoff, the results should not expressively change and it does not. F-statistics suffer small changes, which can be attributed to variations in degrees of freedom, but it remains higher than 10 for all cutoffs.

\subsection{Second stage}

First stage estimates show that wind speed is strongly correlated with pollutant concentration, signaling that it is a good instrument for particulate matter. Now, table 3 brings the results for the second stage. Main results include not only effects of PM on hospitalization rate due to all respiratory diseases, but also effects on pneumonia, asthma and influenza hospitalization rates separately. The table shows results for OLS and 2SLS estimates and marginal effects should be interpreted as a result of an increasing of $10 \mu \mathrm{g} / \mathrm{m}^{3}$ in PM levels.

Comparing OLS and 2SLS estimates gives us the bias direction. Despite a few positive and significant OLS results, its coefficients are much lower than 2SLS estimates revealing a negative bias in the first model. We may think about attenuation bias and/or omitted variable bias. The first one is a natural consequence of proxying pollution exposure using monitoring data. The second might be consequence of an avoidance behavior, which is supposed to be stronger in children between one and five years old as they frequently have outdoor activities that can be interrupted in the most polluted days.

When we disaggregate the results into most recurrent diseases, we find significant impact on pneumonia, asthma and influenza when we consider all ages below 5 . We may think that exposure to more polluted environment leads to a decline in child's immunity, favoring and/or worsening bacterial and viral diseases. On the other hand, for chronic disease, such as asthma in this case, children may have attacks as consequence of poor air quality. It is also worth noting that light hospitalization may be underestimated once the incidence of serious illness is rising and possibly hospital beds are running out. In addition, we cannot control the fact that people may not go to the hospital when the disease is not so strong or if they think that it will take too long to see a doctor.

The results for infants should be cautiously interpreted, since it is hard to determine 
Table 3 - Second stage

\begin{tabular}{|c|c|c|c|c|c|}
\hline & \multicolumn{4}{|c|}{ Hospitalization rate } & \multirow{2}{*}{$\frac{\text { Days }}{\text { Respiratory }}$} \\
\hline & Respiratory & Pneumonia & Asthma & Influenza & \\
\hline \multicolumn{6}{|l|}{$\begin{array}{l}\text { OLS } \\
\text { Ages 0-5 }\end{array}$} \\
\hline$P M_{t}$ & $\begin{array}{c}0.945 * * \\
(0.373)\end{array}$ & $\begin{array}{l}0.300^{*} \\
(0.177)\end{array}$ & $\begin{array}{c}0.0893 \\
(0.0951)\end{array}$ & $\begin{array}{c}0.0317 * * \\
(0.0134)\end{array}$ & $\begin{array}{c}0.0379 \\
(0.0264)\end{array}$ \\
\hline \multicolumn{6}{|l|}{ Ages 1-5 } \\
\hline$P M_{t}$ & $\begin{array}{c}1.028 * * \\
(0.440)\end{array}$ & $\begin{array}{c}0.311 \\
(0.214)\end{array}$ & $\begin{array}{l}0.0963 \\
(0.111)\end{array}$ & $\begin{array}{c}0.0418 * * * \\
(0.0152)\end{array}$ & $\begin{array}{c}0.0403 \\
(0.0278)\end{array}$ \\
\hline \multicolumn{6}{|c|}{ 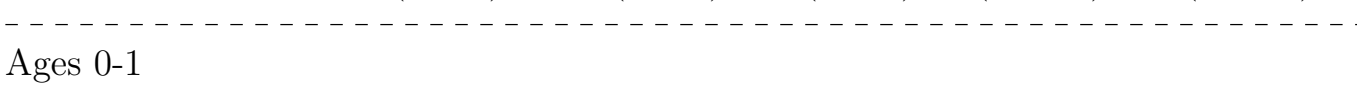 } \\
\hline$P M_{t}$ & $\begin{array}{c}0.531 \\
(0.350)\end{array}$ & $\begin{array}{c}0.246 \\
(0.172)\end{array}$ & $\begin{array}{c}0.0546 \\
(0.0415)\end{array}$ & $\begin{array}{l}-0.0187 \\
(0.0145)\end{array}$ & $\begin{array}{c}0.0123 \\
(0.0102)\end{array}$ \\
\hline \multicolumn{6}{|l|}{$\begin{array}{l}\text { 2SLS } \\
\text { Ages } 0-5\end{array}$} \\
\hline$P M_{t}$ & $\begin{array}{c}3.373^{* * *} \\
(1.175)\end{array}$ & $\begin{array}{l}1.618^{* *} \\
(0.737)\end{array}$ & $\begin{array}{c}0.820^{* *} \\
(0.318)\end{array}$ & $\begin{array}{l}0.0752^{*} \\
(0.0408)\end{array}$ & $\begin{array}{r}-0.141^{* *} \\
(0.0617)\end{array}$ \\
\hline \multicolumn{6}{|c|}{$\begin{array}{l}---------------------------------------------------\cdot-{ }^{\text {Ages } 1-5}\end{array}$} \\
\hline$P M_{t}$ & $\begin{array}{c}3.741^{* * *} \\
(1.345)\end{array}$ & $\begin{array}{l}1.888^{* *} \\
(0.856)\end{array}$ & $\begin{array}{c}0.968^{* *} \\
(0.370)\end{array}$ & $\begin{array}{c}0.0602 \\
(0.0416)\end{array}$ & $\begin{array}{r}-0.111^{* *} \\
(0.0554)\end{array}$ \\
\hline \multicolumn{6}{|c|}{$\begin{array}{l}\text { Ages } 0-1 \\
\text { Agl }\end{array}$} \\
\hline$P M_{t}$ & $\begin{array}{l}1.531 \\
(1.128)\end{array}$ & $\begin{array}{c}0.264 \\
(0.538)\end{array}$ & $\begin{array}{l}0.0747 \\
(0.164)\end{array}$ & $\begin{array}{c}0.150^{*} \\
(0.0792)\end{array}$ & $\begin{array}{c}0.0267 \\
(0.0325) \\
\end{array}$ \\
\hline Number of districts & 77 & 77 & 77 & 77 & 77 \\
\hline Number of days & 1,096 & 1,096 & 1,096 & 1,096 & 1,096 \\
\hline Observations & 78,956 & 78,956 & 78,956 & 78,956 & 78,956 \\
\hline
\end{tabular}

Table shows the results of second stage. In columns, there are regressions for different outcomes. In lines, there are the results for different age groups. We include district, day of the week, month and year fixed effect. We also add temperature and humidity in quadratic form as controls. Standard errors in parentheses are two-way clustered by district and day. To check significance: ${ }^{* * *} \mathrm{p}<0.01,{ }^{* *} \mathrm{p}<0.05$, $* \mathrm{p}<0.1$ 
pollution exposure for this group. Children under one mainly have indoor activities and they are less exposed to external agents, such as virus and bacteria. In that sense, unexpected PM variation due to wind speed may not be too important for this age group as it is for older children. The only significant PM impact for this group is on influenza admission, an easily transmitted disease that strongly affects immune system still in development. Probably, infants are getting influenza indoor from adults, who only go to the hospital if the flu is very severe, unlike children under one year old.

The negative and significant PM effects on the duration of hospitalization for the first and second groups suggest that hospitalizations are becoming shorter than the average. Clearly, the effect on ages 0-5 comes from the effect on children above 1, which is an expected result, since infants may have a stronger reaction than older children and, hence, they have a duration as long as the average hospitalization. In addition, a shorter hospitalization might indicate that its severity is not very intense and, therefore, this admission could be more easily avoided.

As we do for the first stage, we also run the main specification for districts no further than $3 \mathrm{~km}, 7 \mathrm{~km}$ and $10 \mathrm{~km}$ in appendix B.1. The significance of 2SLS marginally changes and hospitalization coefficients magnitude reduces as the cutoff increases. Probably the pollution and meteorology assigned to the furthest districts do not represent the real ones. If this is guiding these changes, then we have evidence that PM 10 levels considerably vary around SPMA.

For child between one and five years old, if PM 10 level increases $10 \mu \mathrm{g} / \mathrm{m}^{3}$ the hospitalization rate due to all respiratory will increase in 3.741 admissions per one million children. Considering the average of all monitors as the measurement of pollution for SPMA, an increase of $10 \mu \mathrm{g} / \mathrm{m}^{3}$ represents around $34 \%$ of the average daily pollution, but it is less than one standard deviation (around $15 \mu \mathrm{g} / \mathrm{m}^{3}$ ), and represents only $13 \%$ in the most polluted day. In terms of child hospitalized, it would increase 3.34 children hospitalized in a day. If we extend this coefficient for the whole region, the number of admission rises to almost 5 children a day.

If we do the same exercise for pneumonia and asthma, we find almost two admissions due to pneumonia and 1.3 due to asthma for children between one and five in SPMA in a day. For infants, it would be more than one admission due to influenza in a month. About the duration of hospitalization, the coefficient of -0.11 represents a reduction of more than two and a half hours relatively to the average duration. This coefficient should be interpreted once we know that hospitalization actually increased. This result may also be conditioned to the increased demand for beds, i.e, this negative coefficient indicate either this additional hospitalizations are shorter or the duration is purposely reduced in order to meet the demand.

Back to the number of 5 additional children hospitalized in a day, if we consider that 
the cost of one day of hospitalization is around $\mathrm{R} \$ 214.88^{1,2}$, additional expenditure would be $\mathrm{R} \$ 1,074.40$ in a day. Considering that a median hospitalization in our data lasts 4 days, for each 5 children, the total hospitalization costs $\mathrm{R} \$ 4,297.60$. In a year, the government would be spending more than BRL 1.5 million, which represents around $\$ 500,000^{3}$. This value is just a lower bound of government spending in SPMA with children hospitalization, once we are not considering other health costs related to air pollution and the SUS table price does not reflect market prices ${ }^{4}$. Nevertheless, this value represents $3.6 \%$ of all SUS expenditure in the city of São Paulo in 2016 with children (aged 1-5) hospitalizations, and around $14 \%$ of expenditure with admissions due to respiratory diseases for this age group in São Paulo.

There is a limited number of studies that investigate impacts of particulate matter on health, which is even smaller for impacts on hospitalization rate for children (especially non-infant children). Neidell (2004) looks at asthma admission for children, but he finds no effect of PM. Although we look at different pollutant, we find a close proportion for asthma admission as Schlenker and Walker (2016), while the authors find the coefficient represents $21 \%$ of average daily rate for all ages, we find $25 \%$ for children, considering an increase of one standard deviation in pollution. Our coefficient for all respiratory represents $10 \%$.

Other studies find negative impact of pollution on fetal and infant health, such as birth weight (CURRIE; WALKER, 2011; CURRIE; NEIDELL; SCHMIEDER, 2009), but they do not look at effects of PM. A greater number of studies look at effects on infant mortality (CURRIE; NEIDELL, 2005; CLAY; LEWIS; SEVERNINI, 2016; ARCEO; HANNA; OLIVA, 2016; JAYACHANDRAN, 2009). Neidell (2004) and Jayachandran (2009) highlight stronger effects on infant from families of low socio-economic status. Although we do not verify effects according to different wages ${ }^{5}$, our dataset counts hospitalizations founded by SUS, which is more common for low income families.

Once we know second stage results, the first stage by itself can give directions to policymakers about how to react in days with weak winds. In business days, when the traffic is more intense, hospitals should pay attention on wind intensity together with weather conditions. If the wind is calm, it may be an indication that pollutants are not dissipating and the hospital will probably be more demanded. As we saw, since these hospitalizations are shorter, if the hospital is ready to receive patients with respiratory problems, a few hospitalization may be avoided.

\footnotetext{
Value for January 2016. Source: DATASUS.

This is a simple average cost per day of hospitalization, not taking into consideration inflation.

We proxy the exchange rate by averaging the average nominal exchange rate of 2015, 2016 and 2017.

As we comment before, the costs available in our dataset is based on a price table of procedures, which are far bellow market prices.

5 We have no information to signalizing the socio-economic status of patient, beyond the zip code of residence (neighborhood socio-economic status).
} 


\subsection{Additional results}

\subsubsection{SUS allocation}

Considering the popular consensus that the public system cannot support its demand, and that our data only refer to SUS hospitalization, what would a positive shock in hospital bed demand provoke? To answer this question, we run the main specification for hospitalizations due to other diseases not related to air pollution. We keep children as the group of analysis, since hospitals tend to separate hospital beds for children and for other ages. If hospital beds are not enough, what is supposed to be a placebo test becomes a variable of impact. Results are in table 4.

Table 4 - Second stage - other diseases

\begin{tabular}{|c|c|c|c|c|c|c|}
\hline & \multicolumn{3}{|c|}{ Hospitalization rate } & \multicolumn{3}{|c|}{ Days } \\
\hline & Phimosis & Hernia & Appendicitis & Phimosis & Hernia & Appendicitis \\
\hline
\end{tabular}

\section{OLS}

Ages 0-5

\begin{tabular}{ccccccc}
$P M_{t}$ & 0.133 & 0.113 & 0.00500 & 0.000319 & 0.00839 & 0.00472 \\
& $(0.121)$ & $(0.0942)$ & $(0.0153)$ & $(0.000959)$ & $(0.00563)$ & $(0.00414)$ \\
\hline
\end{tabular}

Ages 1-5

$\begin{array}{ccccccc}P M_{t} & 0.156 & 0.135 & 0.00794 & 0.000300 & 0.00687 & 0.00478 \\ & (0.145) & (0.111) & (0.0183) & (0.000963) & (0.00504) & (0.00417) \\ -\end{array}$

Ages 0-1

\begin{tabular}{ccccccc}
$P M_{t}$ & 0.0148 & 0.00205 & -0.00965 & 0.0000240 & 0.00162 & -0.0000562 \\
& $(0.0263)$ & $(0.0557)$ & $(0.00777)$ & $(0.0000253)$ & $(0.00211)$ & $(0.0000754)$ \\
\hline
\end{tabular}

\section{SLS}

Ages 0-5

$\begin{array}{lrrrrrr}P M_{t} & -0.355 & -0.130 & 0.0217 & 0.00433 & -0.0164 & -0.00277 \\ - & (0.315) & (0.305) & (0.0735) & (0.00412) & (0.0205) & (0.0168)\end{array}$

Ages 1-5

$\begin{array}{lcccccc}P M_{t} & -0.423 & -0.137 & 0.0232 & 0.00438 & 0.0130 & -0.00299 \\ & (0.378) & (0.370) & (0.0889) & (0.00414) & (0.0118) & (0.0169)\end{array}$

Ages 0-1

\begin{tabular}{lcccccc}
$P M_{t}$ & -0.00984 & -0.0941 & 0.0140 & -0.0000294 & $-0.0291^{*}$ & -0.000273 \\
& $(0.0740)$ & $(0.229)$ & $(0.0287)$ & $(0.0000902)$ & $(0.0162)$ & $(0.000921)$ \\
\hline Number of districts & 77 & 77 & 77 & 77 & 77 & 77 \\
Number of days & 1,096 & 1,096 & 1,096 & 1,096 & 1,096 & 1,096 \\
Observations & 78,956 & 78,956 & 78,956 & 78,956 & 78,956 & 78,956 \\
\hline
\end{tabular}

Table shows the results of second stage for districts no further than $5 \mathrm{~km}$. In columns, there are regressions for different outcomes. In lines, the results for different age groups. We include district, day of the week, month and year fixed effect. We also add temperature and humidity in quadratic form as controls. Standard errors in parentheses are two-way clustered by district and day. To check significance: *** $\mathrm{p}<0.01,{ }^{* *} \mathrm{p}<0.05,{ }^{*} \mathrm{p}<0.1$.

Results point no significant impact of PM on other diseases. It suggests that the 
public system is able to absorb all the demand in terms of payment, since this dataset includes all hospitalizations afforded by SUS, not necessarily in SUS hospitals. SUS has its own hospitals and also beds in philanthropic health centers ${ }^{6}$. It can also agree a few beds with private hospitals. SUS prioritizes beds in publics hospital before philanthropic health center, and it uses beds in private hospital as a last option, always respecting the resources needed in each hospitalization ${ }^{7}$. In order to check this allocation, we run separated 2SLS regressions for two groups of hospitalizations: those occurred in public hospitals, and those in philanthropic or private health centers ${ }^{8}$, as table 5 shows for respiratory diseases. Table 6 shows for phimosis, hernia and appendicitis causes - it is not possible to run this specification for infant hospitalization due to the low number of admission for this group. As table 4 suggests, SUS can afford hospitalization for all who need it (and go to a hospital). Now, we want to investigate if SUS needs to afford beds out of public hospitals to meet the increased demand caused by poor air quality. If this is the situation, we expect positive coefficients for hospitalizations due to any diseases.

Results suggest that public hospitals are absorbing hospitalizations for respiratory causes and almost all others hospitalizations. It indicates that public hospital can deal the total demand for service. We should take into consideration that SUS operation in São Paulo is a reference for the whole country. Almost 35\% of beds in SPMA are located in public hospitals, and more than $55 \%$ of total beds are SUS beds ${ }^{9}$. Furthermore, more than $61 \%$ of pediatric beds are SUS beds. In 2016, the city of São Paulo counted around 3 beds per 1000 people (WHO recommendation is a minimum of 3.5). If we consider only SUS beds, this number will be much lower, but not the entire population is SUS user. São Paulo has also other SUS health units beside hospitals as we discussed in section 1.2.

Another reason that may be guiding our results is that some hospitals are specialized in specific procedures, what would also explain why we do not have enough infant hospitalizations in private hospitals to run the regression. Besides, we are just checking effects for a few diseases and investigation for other diseases is required to rule out any negative externality. Finally, we are not evaluating the service quality.

6 It works by contract. SUS and philanthropic hospitals agree a number of beds for SUS usage, but it only pays if it is used. To be a philanthropic hospital, the hospital needs to allocate at least $60 \%$ of its beds for SUS and, in return, it is exempt from federal tax.

7 Internally obtained information.

8 Public and non-public hospital were established according to National Classification Commission CONCLA.

9 Around $35 \%$ of beds located in private health centers are SUS beds, and around $60 \%$ of beds in philanthropic hospitals are SUS beds. Source: DATASUS (values for Jan/16). 
Table 5 - Allocation between SUS and non-SUS hospitals - respiratory diseases

\begin{tabular}{cccccc}
\hline & \multicolumn{3}{c}{ Hospitalization rate } & & Days \\
\cline { 2 - 4 } \cline { 5 - 6 } & Respiratory & Pneumonia & Asthma & Influenza & Respiratory \\
\hline
\end{tabular}

SUS Hospital

Ages 0-5

$\begin{array}{cccccc}P M_{t} & 3.373^{* * *} & 1.619^{* *} & 0.682^{* *} & 0.0740^{* *} & -0.141^{* *} \\ & (1.175) & (0.696) & (0.298) & (0.0353) & (0.0617)\end{array}$

Ages 1-5

$\begin{array}{llllll}P M_{t} & 3.741^{* * *} & 1.894^{* *} & 0.801^{* *} & 0.0583^{*} & -0.111^{* *}\end{array}$

$(1.345) \quad(0.808) \quad(0.343) \quad(0.0326) \quad(0.0554)$

Ages 0-1

\begin{tabular}{cccccc}
$P M_{t}$ & 1.531 & 0.247 & 0.0807 & $0.152^{*}$ & 0.0267 \\
& $(1.128)$ & $(0.536)$ & $(0.160)$ & $(0.0793)$ & $(0.0325)$ \\
\hline
\end{tabular}

Non-SUS Hospital

Ages 0-5

$\begin{array}{cccccc}P M_{t} & 0.0163 & -0.00605 & -0.00168 & -0.0620 & 0.0163 \\ & (0.0170) & (0.00654) & (0.00348) & (0.107) & (0.0170)\end{array}$

Ages 1-5

$\begin{array}{lccccc}P M_{t} & 0.320 & -0.00534 & 0.167^{*} & 0.00182 & -0.0523 \\ & (0.272) & (0.124) & (0.0939) & (0.0200) & (0.0319)\end{array}$

Ages 0-1

\begin{tabular}{lccccc}
$P M_{t}$ & 0.0369 & 0.0163 & -0.00605 & -0.00168 & -0.00361 \\
& $(0.162)$ & $(0.0170)$ & $(0.00654)$ & $(0.00348)$ & $(0.0106)$ \\
\hline Number of districts & 77 & 77 & 77 & 77 & 77 \\
Number of days & 1,096 & 1,096 & 1,096 & 1,096 & 1,096 \\
Observations & 78,956 & 78,956 & 78,956 & 78,956 & 78,956 \\
\hline
\end{tabular}

Table shows separated 2SLS results for hospitalizations in public and non-public hospitals. There is no results for children under 1 because there is not enough infant hospitalizations in private hospitals. We include district, day of the week, month and year fixed effect. We also add temperature and humidity in quadratic form as controls. Standard errors in parentheses are two-way clustered by district and day. To check significance: $* * * \mathrm{p}<0.01,{ }^{*} * \mathrm{p}<0.05,{ }^{*} \mathrm{p}<0.1$. 
Table 6 - Allocation between SUS and non-SUS hospitals - other diseases

\begin{tabular}{|c|c|c|c|c|c|c|}
\hline & \multicolumn{3}{|c|}{ Hospitalization rate } & \multicolumn{3}{|c|}{ Days } \\
\hline & Phimosis & Hernia & Appendicitis & Phimosis & Hernia & Appendicitis \\
\hline \multicolumn{7}{|l|}{ SUS Hospital } \\
\hline \multicolumn{7}{|l|}{ Ages $0-5$} \\
\hline$P M_{t}$ & $\begin{array}{l}-0.424 \\
(0.305)\end{array}$ & $\begin{array}{l}-0.181 \\
(0.302)\end{array}$ & $\begin{array}{c}0.0117 \\
(0.0669)\end{array}$ & $\begin{array}{c}0.00357 \\
(0.00402)\end{array}$ & $\begin{array}{l}-0.0134 \\
(0.0206)\end{array}$ & $\begin{array}{r}-0.00592 \\
(0.0166)\end{array}$ \\
\hline \multicolumn{7}{|l|}{ Ages 1-5 } \\
\hline$P M_{t}$ & $\begin{array}{l}-0.506 \\
(0.366)\end{array}$ & $\begin{array}{l}-0.200 \\
(0.365)\end{array}$ & $\begin{array}{c}0.0112 \\
(0.0803)\end{array}$ & $\begin{array}{c}0.00362 \\
(0.00404)\end{array}$ & $\begin{array}{c}0.0142 \\
(0.0114)\end{array}$ & $\begin{array}{c}-0.00614 \\
(0.0167)\end{array}$ \\
\hline \multicolumn{7}{|l|}{ Ages 0-1 } \\
\hline$P M_{t}$ & $\begin{array}{c}-0.00984 \\
(0.0740)\end{array}$ & $\begin{array}{c}-0.0884 \\
(0.229)\end{array}$ & $\begin{array}{c}0.0140 \\
(0.0287)\end{array}$ & $\begin{array}{c}-0.0000294 \\
(0.0000902)\end{array}$ & $\begin{array}{c}-0.0271^{*} \\
(0.0162)\end{array}$ & $\begin{array}{c}-0.000273 \\
(0.000921)\end{array}$ \\
\hline \multicolumn{7}{|l|}{ Non-SUS Hospital } \\
\hline \multicolumn{7}{|l|}{ Ages 0-5 } \\
\hline$P M_{t}$ & $\begin{array}{c}0.0692^{* *} \\
(0.0330)\end{array}$ & $\begin{array}{c}0.0517 \\
(0.0442)\end{array}$ & $\begin{array}{c}0.0101 \\
(0.0194)\end{array}$ & $\begin{array}{c}0.000553 \\
(0.000861)\end{array}$ & $\begin{array}{l}-0.00328 \\
(0.00261)\end{array}$ & $\begin{array}{c}0.00314 \\
(0.00386)\end{array}$ \\
\hline \multicolumn{7}{|l|}{ Ages 1-5 } \\
\hline$P M_{t}$ & $\begin{array}{c}0.0830^{* *} \\
(0.0397)\end{array}$ & $\begin{array}{c}0.0631 \\
(0.0538)\end{array}$ & $\begin{array}{c}0.0121 \\
(0.0233)\end{array}$ & $\begin{array}{c}0.000556 \\
(0.000861)\end{array}$ & $\begin{array}{l}-0.00150 \\
(0.00157)\end{array}$ & $\begin{array}{c}0.00315 \\
(0.00386)\end{array}$ \\
\hline Number of districts & 77 & 77 & 77 & 77 & 77 & 77 \\
\hline Number of days & 1,096 & 1,096 & 1,096 & 1,096 & 1,096 & 1,096 \\
\hline Observations & 78,956 & 78,956 & 78,956 & 78,956 & 78,956 & 78,956 \\
\hline
\end{tabular}

Table shows separated 2SLS results for hospitalizations in public and non-public hospitals. We include district, day of the week, month and year fixed effect. We also add temperature and humidity in quadratic form as controls. Standard errors in parentheses are two-way clustered by district and day. To check significance: ${ }^{* * *} \mathrm{p}<0.01,{ }^{* *} \mathrm{p}<0.05,{ }^{*} \mathrm{p}<0.1$.

\subsubsection{Lagged PM 10}

With the purpose of investigating the cumulative effect of air pollution, we add to the main model two pollution lags together with the contemporaneous pollution ${ }^{10}$. Results of first stage are in table 7 and second stage in table 8 . We report cumulative coefficient (sum of coefficients) for both fist and second stage. In the first, we just want to show that it is capturing almost the same for $P M_{t}, P M_{t-1}$ and $P M_{t-2}$. For the second stage, cumulative represents the cumulative effect of PM 10 on hospitalizations.

This first stage can be seen as a robustness, since wind speed days ahead cannot be correlated to previous PM 10, once we control for contemporaneous pollution (second and third columns for each age group). Furthermore, wind speed two days before admission seems to have no effect on contemporaneous PM, suggesting that environmental conditions

10 To keep consistency with the main specification, we use four instruments: $w s_{t}, w s_{t-1}, w s_{t-2}$ and $w s_{t-3}$. Both first stages and second stage are controlled by control $_{t}$, control $_{t-1}$ and control $_{t-2}$. 
Table 7 - First stage - two lags

\begin{tabular}{|c|c|c|c|c|c|c|c|c|c|}
\hline & \multicolumn{3}{|c|}{ Ages 0-5 } & \multicolumn{3}{|c|}{ Ages 1-5 } & \multicolumn{3}{|c|}{ Ages 0-1 } \\
\hline & $P M_{t}$ & $P M_{t-1}$ & $P M_{t-2}$ & $P M_{t}$ & $P M_{t-1}$ & $P M_{t-2}$ & $P M_{t}$ & $P M_{t-1}$ & $P M_{t-2}$ \\
\hline$w s_{t}$ & $\begin{array}{c}-0.612^{* * *} \\
(0.0530)\end{array}$ & $\begin{array}{c}0.0598 \\
(0.0441)\end{array}$ & $\begin{array}{c}0.0353 \\
(0.0422)\end{array}$ & $\begin{array}{c}-0.612^{* * *} \\
(0.0530)\end{array}$ & $\begin{array}{c}0.0598 \\
(0.0441)\end{array}$ & $\begin{array}{c}0.0352 \\
(0.0422)\end{array}$ & $\begin{array}{c}-0.612^{* * *} \\
(0.0529)\end{array}$ & $\begin{array}{c}0.0599 \\
(0.0441)\end{array}$ & $\begin{array}{c}0.0357 \\
(0.0422)\end{array}$ \\
\hline$w s_{t-1}$ & $\begin{array}{c}-0.242^{* * *} \\
(0.0487)\end{array}$ & $\begin{array}{c}-0.630^{* * *} \\
(0.0628)\end{array}$ & $\begin{array}{c}0.0376 \\
(0.0487)\end{array}$ & $\begin{array}{c}-0.242^{* * *} \\
(0.0487)\end{array}$ & $\begin{array}{c}-0.630^{* * *} \\
(0.0628)\end{array}$ & $\begin{array}{c}0.0376 \\
(0.0487)\end{array}$ & $\begin{array}{c}-0.243^{* * *} \\
(0.0487)\end{array}$ & $\begin{array}{c}-0.630^{* * *} \\
(0.0627)\end{array}$ & $\begin{array}{c}0.0373 \\
(0.0487)\end{array}$ \\
\hline$w s_{t-2}$ & $\begin{array}{c}0.00914 \\
(0.0440)\end{array}$ & $\begin{array}{c}-0.259^{* * *} \\
(0.0487)\end{array}$ & $\begin{array}{c}-0.658^{* * *} \\
(0.0668)\end{array}$ & $\begin{array}{c}0.00917 \\
(0.0440)\end{array}$ & $\begin{array}{c}-0.259^{* * *} \\
(0.0487)\end{array}$ & $\begin{array}{c}-0.658^{* * *} \\
(0.0668)\end{array}$ & $\begin{array}{c}0.00898 \\
(0.0441)\end{array}$ & $\begin{array}{c}-0.260^{* * *} \\
(0.0486)\end{array}$ & $\begin{array}{r}-0.658^{* * *} \\
(0.0667)\end{array}$ \\
\hline$w s_{t-3}$ & $\begin{array}{c}0.0638 \\
(0.0404) \\
\end{array}$ & $\begin{array}{c}0.0379 \\
(0.0413)\end{array}$ & $\begin{array}{c}-0.219^{* * *} \\
(0.0481)\end{array}$ & $\begin{array}{c}0.0638 \\
(0.0403)\end{array}$ & $\begin{array}{c}0.0380 \\
(0.0413)\end{array}$ & $\begin{array}{c}-0.219^{* * *} \\
(0.0481)\end{array}$ & $\begin{array}{c}0.0639 \\
(0.0404)\end{array}$ & $\begin{array}{c}0.0378 \\
(0.0414)\end{array}$ & $\begin{array}{r}-0.220^{* * *} \\
(0.0480)\end{array}$ \\
\hline F-statistic & 42.87 & 41.42 & 40.21 & 42.84 & 41.37 & 40.15 & 43.03 & 41.66 & 40.47 \\
\hline Cumulative & -0.856 & -0.791 & -0.804 & -1.064 & -0.791 & -0.804 & -1.064 & -0.792 & -0.804 \\
\hline Number of districts & 77 & 77 & 77 & 77 & 77 & 77 & 77 & 77 & 77 \\
\hline Number of days & 1,094 & 1,094 & 1,094 & 1,094 & 1,094 & 1,094 & 1,094 & 1,094 & 1,094 \\
\hline Observations & 78,774 & 78,774 & 78,774 & 78,774 & 78,774 & 78,774 & 78,774 & 78,774 & 78,774 \\
\hline
\end{tabular}

The table shows the results of first stages of a model with multiples endogenous $\left(P M_{t}, P M_{t-1}\right.$ and $\left.P M_{t-2}\right)$. F-statistics refer to the test of joint significance of instruments. Standard errors in parentheses are two-way clustered by district and day. To check significance: $* * * \mathrm{p}<0.01,{ }^{* *} \mathrm{p}<0.05, *$ $\mathrm{p}<0.1$.

change in a couple of days. F-statistics are (enough) high in all situations and coefficients between age groups are similar since they only differ in the weight.

The second stage makes sense for a few reasons beyond the cumulative effect. We may think that the day of admission may vary with parents concern about child health. Parents may take the child to the hospital as soon as the symptoms appear or they may delay a couple of days if they think it would not be a problem, which would underestimate the results of a contemporaneous model, since contemporaneous pollution is also impacting future hospitalization. On the other hand, a period of consecutive days of poor air quality may have a higher hospitalization rate in the first days of this period guided by children with more fragile health. In this case, people are only anticipating a hospitalization that would occur anyway, and contemporaneous model would overestimate the real coefficient ${ }^{11}$. This temporal displacement is discussed by Schlenker and Walker (2016).

Looking at the second stage, the sum of coefficients for children between one and five years old increases, pointing that cumulative effect is important. Positive and significant lagged pollution suggests that people delay hospital visit, so contemporaneous model estimates are underestimated. The direction and significance of PM effect on duration of hospitalization are interesting. We may think that if people are waiting to go to the hospital, the disease is worsening, resulting in a hospitalization closer to the average in the next days, as the positive and non-significant coefficient of $P M_{t-2}$ shows (the earliest coefficient is significant in table 8 in appendix B.2). But, if people decide to not wait, then the severity of the disease is lower than the average hospitalization severity, explaining the negative and significant of contemporaneous PM 10. As we have opposite direction, the cumulative effect is close to zero.

$\overline{11}$ If people delay hospital visit, we will expect positive lagged pollution, but if they anticipate, then lagged PM 10 should be negative. 
Table 8 - Second stage - two lags

\begin{tabular}{|c|c|c|c|c|c|}
\hline & \multicolumn{4}{|c|}{ Hospitalization rate } & \multirow{2}{*}{$\frac{\text { Days }}{\text { Respiratory }}$} \\
\hline & Respiratory & Pneumonia & Asthma & Influenza & \\
\hline \multicolumn{6}{|l|}{ Ages 0-5 } \\
\hline$P M_{t}$ & $\begin{array}{c}2.078 \\
(1.462)\end{array}$ & $\begin{array}{c}0.928 \\
(0.988)\end{array}$ & $\begin{array}{c}0.456 \\
(0.351)\end{array}$ & $\begin{array}{c}0.119^{*} \\
(0.0655)\end{array}$ & $\begin{array}{c}-0.156^{*} \\
(0.0903)\end{array}$ \\
\hline$P M_{t-1}$ & $\begin{array}{c}0.736 \\
(1.800)\end{array}$ & $\begin{array}{c}0.571 \\
(1.178)\end{array}$ & $\begin{array}{c}0.251 \\
(0.363)\end{array}$ & $\begin{array}{c}-0.0396 \\
(0.0674)\end{array}$ & $\begin{array}{c}-0.0554 \\
(0.178)\end{array}$ \\
\hline$P M_{t-2}$ & $\begin{array}{l}4.259^{* *} \\
(1.642)\end{array}$ & $\begin{array}{c}2.196^{* *} \\
(0.893)\end{array}$ & $\begin{array}{c}0.964^{* *} \\
(0.411)\end{array}$ & $\begin{array}{c}0.0878 \\
(0.0625)\end{array}$ & $\begin{array}{c}0.177 \\
(0.128)\end{array}$ \\
\hline Cumulative & $\begin{array}{l}7.07 * * * \\
(1.744)\end{array}$ & $\begin{array}{c}3.69^{* * *} \\
(0.960)\end{array}$ & $\begin{array}{c}1.67^{* * *} \\
(0.496)\end{array}$ & $\begin{array}{c}0.17^{* * *} \\
(0.061)\end{array}$ & $\begin{array}{c}-0.03 \\
(0.110)\end{array}$ \\
\hline \multicolumn{6}{|l|}{ Ages 1-5 } \\
\hline$P M_{t}$ & $\begin{array}{c}2.596 \\
(1.694)\end{array}$ & $\begin{array}{c}1.344 \\
(1.155)\end{array}$ & $\begin{array}{c}0.533 \\
(0.414)\end{array}$ & $\begin{array}{c}0.111 \\
(0.0672)\end{array}$ & $\begin{array}{l}-0.0968 \\
(0.0732)\end{array}$ \\
\hline$P M_{t-1}$ & $\begin{array}{c}0.299 \\
(2.079)\end{array}$ & $\begin{array}{c}0.188 \\
(1.385)\end{array}$ & $\begin{array}{c}0.309 \\
(0.426)\end{array}$ & $\begin{array}{c}-0.0582 \\
(0.0767)\end{array}$ & $\begin{array}{c}-0.0933 \\
(0.151)\end{array}$ \\
\hline$P M_{t-2}$ & $\begin{array}{l}5.009^{* *} \\
(1.914)\end{array}$ & $\begin{array}{c}2.751^{* *} \\
(1.046)\end{array}$ & $\begin{array}{l}1.135^{* *} \\
(0.487)\end{array}$ & $\begin{array}{c}0.0933 \\
(0.0608)\end{array}$ & $\begin{array}{c}0.154 \\
(0.110)\end{array}$ \\
\hline Cumulative & $\begin{array}{c}7.90^{* * *} \\
(2.019)\end{array}$ & $\begin{array}{c}4.28^{* * *} \\
(1.131)\end{array}$ & $\begin{array}{c}1.98^{* * *} \\
(0.580)\end{array}$ & $\begin{array}{c}0.15^{* * *} \\
(0.055)\end{array}$ & $\begin{array}{c}-0.04 \\
(0.102)\end{array}$ \\
\hline \multicolumn{6}{|l|}{ Ages 0-1 } \\
\hline$P M_{t}$ & $\begin{array}{c}-0.521 \\
(1.210)\end{array}$ & $\begin{array}{l}-1.158 \\
(0.743)\end{array}$ & $\begin{array}{l}0.0712 \\
(0.178)\end{array}$ & $\begin{array}{c}0.160 \\
(0.107)\end{array}$ & $\begin{array}{l}-0.0137 \\
(0.0575)\end{array}$ \\
\hline$P M_{t-1}$ & $\begin{array}{c}2.941^{* *} \\
(1.272)\end{array}$ & $\begin{array}{c}2.497^{* * *} \\
(0.854)\end{array}$ & $\begin{array}{c}-0.0362 \\
(0.163)\end{array}$ & $\begin{array}{c}0.0535 \\
(0.0915)\end{array}$ & $\begin{array}{c}0.0210 \\
(0.0839)\end{array}$ \\
\hline$P M_{t-2}$ & $\begin{array}{c}0.502 \\
(1.165)\end{array}$ & $\begin{array}{l}-0.583 \\
(0.746) \\
\end{array}$ & $\begin{array}{c}0.108 \\
(0.195) \\
\end{array}$ & $\begin{array}{l}0.0601 \\
(0.143)\end{array}$ & $\begin{array}{c}0.0936 \\
(0.0979)\end{array}$ \\
\hline Cumulative & $\begin{array}{c}2.92^{*} \\
(1.688) \\
\end{array}$ & $\begin{array}{c}0.76 \\
(0.824) \\
\end{array}$ & $\begin{array}{c}0.14 \\
(0.250)\end{array}$ & $\begin{array}{c}0.27 \\
(0.159)\end{array}$ & $\begin{array}{c}0.10 \\
(0.067)\end{array}$ \\
\hline Number of districts & 77 & 77 & 77 & 77 & 77 \\
\hline Number of days & 1,094 & 1,094 & 1,094 & 1,094 & 1,094 \\
\hline Observations & 78,774 & 78,774 & 78,774 & 78,774 & 78,774 \\
\hline
\end{tabular}

Table shows the results of second stage for districts no further than $5 \mathrm{~km}$ including lagged pollution together with contemporaneous PM 10 as independent variable. Standard errors in parentheses are two-way clustered by district and day. To check significance: ${ }^{* * *} \mathrm{p}<0.01,{ }^{* *} \mathrm{p}<0.05,{ }^{*} \mathrm{p}<0.1$. 
In appendix B.2, we also run regressions adding only $P M_{t-1}$ and adding $P M_{t-1}$, $P M_{t-2}$ and $P M_{t-3}$. Cumulative coefficients for children between one and five increase as we add more pollution lags, while coefficients for infants do not expressively change. In addition, since the coefficient of the first lag is the only significant in all specifications for children under one, temporal displacement is not long for this age group.

\subsubsection{PM 10 and $\mathrm{O} 3$}

Multi-pollutant model is still a challenge in literature due to the difficulty of isolating effects for each pollutant (BELL; KIM; DOMINICI, 2007; CURRIE; NEIDELL, 2005). Considering that PM and O3 are frequently pointed as the main problem in SPMA, we take the advantage that O3 is a secondary pollutant, i.e., it is not directly emitted, and its formation requires solar radiation to separate the effects of each pollutant.

The idea of including more than one endogenous in a specification, and being able to isolate causal effects for both, needs not only as many instruments as endogenous, but also one instrument particularly strong for one and not so strong for other endogenous. This instrument would be responsible for capturing an exogenous variation of an endogenous variable without varying the others a lot. In that sense, we keep the wind speed and we also add solar radiation to the instruments. The two stages are:

$$
\begin{gathered}
\text { Pol }_{i t}=\alpha+\beta_{1} w s_{i t}+\beta_{2} w s_{i t-1}+\beta_{3} s r_{i t}+\pi \text { controls }_{i t}+\theta_{i}+\mu_{t}+\epsilon_{i t} ; \quad \text { (1st stage) } \\
\text { Pol }_{i t}=P M_{i t}, O 3_{i t} \\
\text { health }_{i t}=\gamma+\lambda_{1} \hat{P M_{i t}}+\lambda_{2} \hat{O} 3_{i t}+\sigma \text { controls }_{i t}+\eta_{i}+\delta_{t}+\varepsilon_{i t} \text { (2nd stage) }
\end{gathered}
$$

Using solar radiation as instrument requires a few considerations: 1) we only use contemporaneous solar radiation because ozone dissipates during the night; 2) part of solar radiation is reflected by clouds. This is not a problem if we consider that controls are capturing the presence of clouds, which does not seem to be too strong, since clouds are formed by water and we are controlling for humidity; 3) a few studies argue that the solar radiation is impacted by air pollutants, either absorbing or reflecting. Considering that the purpose of first stage is capturing a correlation, not a causality, this should not be a concerning. Furthermore, the first stage bellow shows no correlation between PM 10 e solar radiation.

As we commented before, solar radiation has no correlation with PM 10 and it is strongly associated to ozone. The wind speed correlation with PM keeps the same as previous regression, but the wind speed correlation with $\mathrm{O} 3$ is curious and we have no exactly answer for that. Ozone formation depends on NOx and VOC concentrations in a function close to a Leontief (see figure 10 in appendix B.2). Studies point that ozone formation at SPMA is volatile organic compounds (VOC) limited, with just a few nitrogen oxides (NOx) limited places in the peripheral area (MARTINS; ANDRADE, 2008; 
Table 9 - First stage - PM 10 and O3

\begin{tabular}{|c|c|c|c|c|c|c|}
\hline & \multicolumn{2}{|c|}{ Ages 0-5 } & \multicolumn{2}{|c|}{ Ages 1-5 } & \multicolumn{2}{|c|}{ Ages 0-1 } \\
\hline & $\mathrm{PM}$ & O3 & $\mathrm{PM}$ & O3 & $\mathrm{PM}$ & O3 \\
\hline$w s_{t}$ & $\begin{array}{c}-0.631^{* * *} \\
(0.0602)\end{array}$ & $\begin{array}{c}0.230 * * * \\
(0.0560)\end{array}$ & $\begin{array}{c}-0.631^{* * *} \\
(0.0602)\end{array}$ & $\begin{array}{c}0.230^{* * *} \\
(0.0559)\end{array}$ & $\begin{array}{c}-0.630 * * * \\
(0.0601)\end{array}$ & $\begin{array}{c}0.229 * * * \\
(0.0560)\end{array}$ \\
\hline$w s_{t-1}$ & $\begin{array}{c}-0.180^{* * *} \\
(0.0468)\end{array}$ & $\begin{array}{c}-0.119^{* *} \\
(0.0494)\end{array}$ & $\begin{array}{c}-0.180^{* * *} \\
(0.0468)\end{array}$ & $\begin{array}{c}-0.119 * * \\
(0.0494)\end{array}$ & $\begin{array}{c}-0.180^{* * *} \\
(0.0466)\end{array}$ & $\begin{array}{c}-0.119^{* *} \\
(0.0495)\end{array}$ \\
\hline$s r_{t}$ & $\begin{array}{l}0.0000315 \\
(0.000730)\end{array}$ & $\begin{array}{c}0.00611^{* * *} \\
(0.000701)\end{array}$ & $\begin{array}{c}0.0000310 \\
(0.000731)\end{array}$ & $\begin{array}{c}0.00610 * * * \\
(0.000702)\end{array}$ & $\begin{array}{l}0.0000344 \\
(0.000729)\end{array}$ & $\begin{array}{r}0.00614^{* * *} \\
(0.000698)\end{array}$ \\
\hline F-statistic & 49.25 & 33.41 & 49.20 & 33.35 & 49.49 & 33.74 \\
\hline Number of monitors & 59 & 59 & 59 & 59 & 59 & 59 \\
\hline Number of days & 1,096 & 1,096 & 1,096 & 1,096 & 1,096 & 1,096 \\
\hline Observations & 58,882 & 58,882 & 58,882 & 58,882 & 58,882 & 58,882 \\
\hline
\end{tabular}

Table shows the results of first stage: regression of PM 10 and O3 on wind speed on the day and one day before admission and contemporaneous solar radiation. Columns represent regressions for different groups (weights). F-statistics refer to the test of joint significance of instruments. Standard errors in parentheses are two-way clustered by district and day. To check significance: ${ }^{* * *} \mathrm{p}<0.01,{ }^{* *} \mathrm{p}<0.05,{ }^{*} \mathrm{p}<0.1$.

SALVO; WANG, 2017). Since almost all monitors are in the central area, probably the O3 formation is VOC limited here. As the ozone formation function suggests, levels of ozone can increase even if NOx reduces (also discussed by Martins and Andrade (2008)). So, the contemporaneous wind speed might become VOC and NOx levels more homogeneous, reducing NOx and increasing VOC around the monitors, resulting in increased O3 formation. Since ozone is destroyed during the night, wind speed one day before has no effect on this phenomenon, and it is reducing the baseline concentrations of ozone precursors in the next day. The direction of wind speed coefficient still demands more investigation, but this is a first shot.

Results for the second stage can be seen in table 10. Comparing OLS and 2SLS for PM 10, we have the same behavior as in the single pollutant model previously shown. For O3, coefficients are higher in 2SLS model for ages 0-5, except for influenza. It is worth noting that the direction of O3 impact changes from negative to positive despite non-significant, suggesting not only an attenuation bias. Coefficients for duration of hospitalization keep the direction, but it loses significance, possibly because of high standard error. In addition, we almost do not see considerable changes from 2SLS in the main specification and here, which can be interpreted as a robustness.

For children under one, pneumonia, asthma and influenza are not guiding the increase in $\mathrm{O} 3$ coefficient for all respiratory, since it is the only one that rises. Again, pollution exposure for infants is difficult to determine, specially for O3 that may not be found indoor. The numbers of districts and observations change because regressions are restricted to monitors that measure both pollutants.

Finally, the purpose of our multi-pollutant model is not rule out the effects of ozone 
Table 10 - Second stage - PM 10 and O3

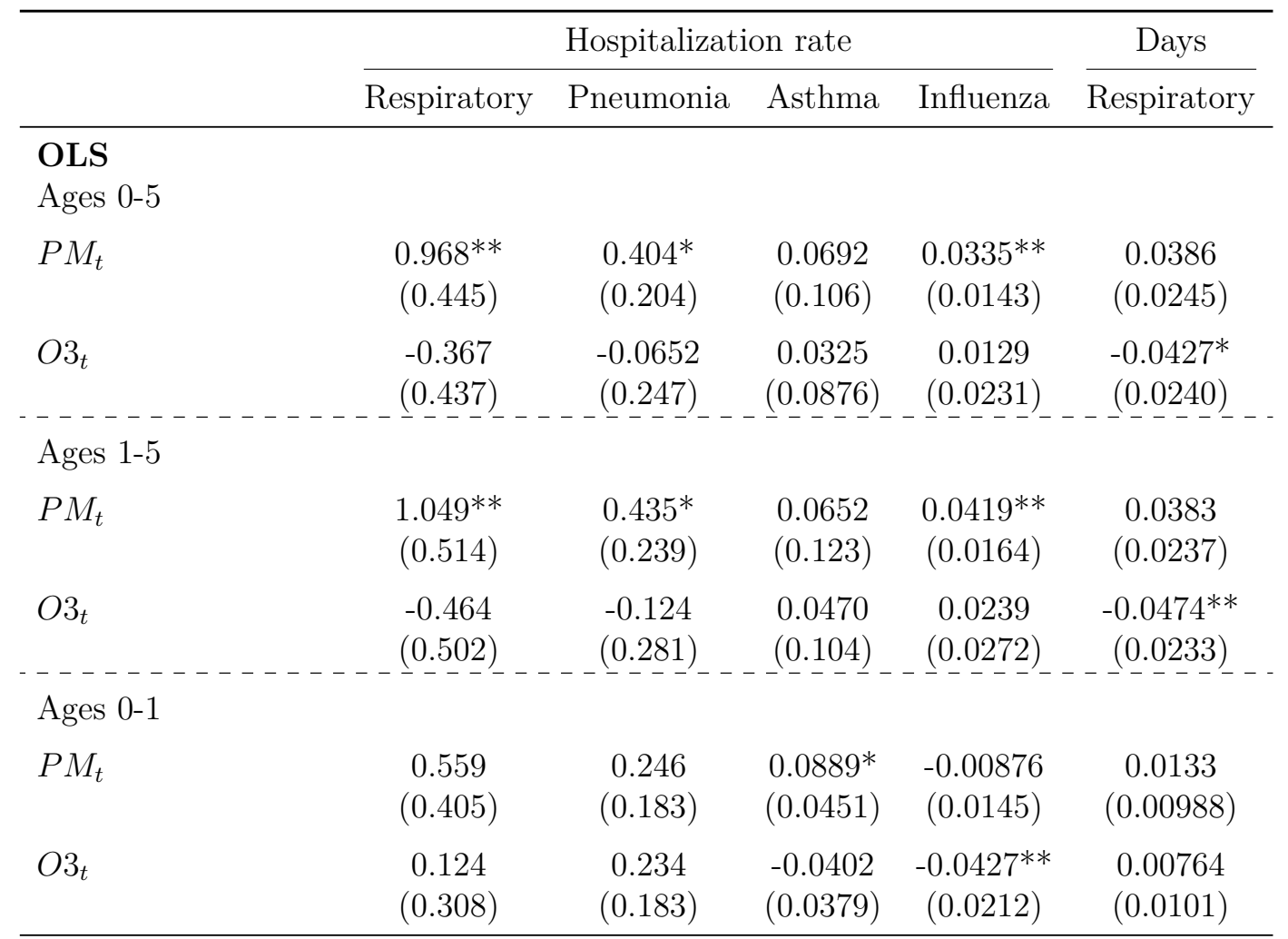

\section{SLS}

Ages 0-5

\begin{tabular}{cccccc}
$P M_{t}$ & $3.308^{* *}$ & $1.829^{*}$ & $0.918^{* *}$ & 0.0513 & $-0.188^{* *}$ \\
& $(1.371)$ & $(0.923)$ & $(0.377)$ & $(0.0467)$ & $(0.0742)$ \\
$O 3_{t}$ & 0.362 & -0.0138 & 0.136 & -0.0617 & -0.0969 \\
& $(1.821)$ & $(1.158)$ & $(0.394)$ & $(0.0531)$ & $(0.0900)$ \\
\hline
\end{tabular}

Ages 1-5

\begin{tabular}{lccccc}
$P M_{t}$ & $3.586^{* *}$ & $2.165^{* *}$ & $1.064^{* *}$ & 0.0324 & $-0.155^{* *}$ \\
& $(1.587)$ & $(1.073)$ & $(0.442)$ & $(0.0481)$ & $(0.0657)$ \\
$O 3_{t}$ & 0.332 & 0.0222 & 0.180 & -0.0577 & -0.0822 \\
- & $(2.041)$ & $(1.303)$ & $(0.480)$ & $(0.0552)$ & $(0.0872)$ \\
Ages 0-1 & & & & & \\
$P M_{t}$ & 1.915 & 0.142 & 0.180 & 0.146 & 0.0224 \\
& $(1.284)$ & $(0.749)$ & $(0.142)$ & $(0.0887)$ & $(0.0365)$ \\
$O 3_{t}$ & 0.544 & -0.179 & -0.0760 & -0.0820 & -0.00551 \\
& $(1.439)$ & $(1.001)$ & $(0.188)$ & $(0.107)$ & $(0.0909)$ \\
\hline Number of monitors & 59 & 59 & 59 & 59 & 59 \\
Number of days & 1,096 & 1,096 & 1,096 & 1,096 & 1,096 \\
Observations & 58,882 & 58,882 & 58,882 & 58,882 & 58,882 \\
\hline
\end{tabular}

Table shows the results of second stage for districts no further than $5 \mathrm{~km}$ including O3 together with PM 10 as independent variable. Standard errors in parentheses are two-way clustered by district and day. To check significance: ${ }^{* * *} \mathrm{p}<0.01,{ }^{* *} \mathrm{p}<0.05,{ }^{*} \mathrm{p}<0.1$. 
on health. We only find that marginal O3 increasing does not seem to be problematic given the average daily O3 concentration in SPMA. Cities with different O3 average should not neglect its possible effects on health and we should try a model with 8h-average, not daily average, in order to confirm our results. A more comprehensive investigation may require pollution non-linear effects.

\subsection{Robustness check}

A few tests are done in order to check robustness. As we do in the main results, all regressions refer to the main specification using districts no further than $5 \mathrm{~km}$.

Table 11 brings the results for the first stage. We only run regressions for the first group, since estimates for different groups do not change a lot. All regressions use contemporaneous PM as dependent variable. The idea of the first four columns is to check if wind speed days ahead or days before the admission impacts contemporaneous PM. The ideal result would be non-significant coefficients for days ahead, but if we consider pollution auto-correlation, a coefficient with the same direction as contemporaneous wind speed is natural, once we do not control for it. The third column supports that significant results of the first two columns come from PM auto-correlation, since coefficients days ahead lose significance once we control for contemporaneous air pollution.

Table 11 - First stage - placebo

\begin{tabular}{lcccccc}
\hline & \multicolumn{5}{c}{ Ages 0-5 } \\
\cline { 2 - 7 } & $P M_{t}$ & $P M_{t}$ & $P M_{t}$ & $P M_{t}$ & $P M_{t}$ & $P M_{t}^{*}$ \\
\hline$w s_{t+2}$ & $-0.106^{* *}$ & & 0.000973 & 0.0173 & 0.0132 & \\
& $(0.0439)$ & & $(0.0414)$ & $(0.0424)$ & $(0.0425)$ & \\
$w s_{t+1}$ & & $-0.309^{* * *}$ & 0.0176 & -0.0104 & -0.0124 & \\
& & $(0.0459)$ & $(0.0478)$ & $(0.0468)$ & $(0.0468)$ & \\
$w s_{t}$ & & & $-0.751^{* * *}$ & $-0.660^{* * *}$ & $-0.652^{* * *}$ & $-0.604^{* * *}$ \\
& & & $(0.0669)$ & $(0.0638)$ & $(0.0635)$ & $(0.0618)$ \\
$w s_{t-1}$ & & & & $-0.189^{* * *}$ & $-0.218^{* * *}$ & $-0.226^{* * *}$ \\
& & & & $(0.0471)$ & $(0.0513)$ & $(0.0461)$ \\
$w s_{t-2}$ & & & & & 0.0556 & \\
& & & & & $(0.0438)$ & \\
\hline F-statistic & 5.88 & 45.38 & 54.68 & 42.96 & 42.55 & 64.69 \\
Number of districts & 77 & 77 & 77 & 77 & 77 & 77 \\
Number of days & 1,094 & 1,095 & 1,094 & 1,094 & 1,093 & 1,096 \\
Observations & 78,820 & 78,888 & 78,820 & 78,820 & 78,751 & 78,956 \\
\hline
\end{tabular}

The table shows the results for different first stages. Each column represents a different regression. Standard errors in parentheses are two-way clustered by district and day. To check significance: ${ }^{* * *} \mathrm{p}<0.01, * *$ $\mathrm{p}<0.05, * \mathrm{p}<0.1$.

Despite correlated, first column shows that wind speed two days ahead is not 
strongly correlated with contemporaneous PM (low F-statistic). In the same way, fifth column shows that contemporaneous and one lagged wind speed capture almost all contemporaneous PM variation, justifying the choice of instruments. In the sixth column, we add bins for each $60^{\circ}$ interval of wind direction as controls and coefficients briefly change comparing to the first stage of main specification. The F-statistic is lower, but still high to consider these as good instruments. The second stage also controlled for wind direction bins is in table 12 below.

Table 12 - Second stage - robustness

\begin{tabular}{llllll}
\hline & \multicolumn{3}{c}{ Hospitalization rate } & & Days \\
\cline { 2 - 3 } \cline { 5 - 6 } & Respiratory & Pneumonia & Asthma & Influenza & Respiratory \\
\hline
\end{tabular}

\section{OLS}

Ages 0-5

$\begin{array}{cccccc}P M_{t} & 0.849^{* *} & 0.266 & 0.0725 & 0.0297^{* *} & 0.0468^{*} \\ & (0.396) & (0.187) & (0.0933) & (0.0131) & (0.0266)\end{array}$

Ages 1-5

$\begin{array}{cccccc}P M_{t} & 0.909^{*} & 0.266 & 0.0763 & 0.0389^{* * *} & 0.0462 \\ & (0.465) & (0.225) & (0.109) & (0.0146) & (0.0283)\end{array}$

Ages 0-1

\begin{tabular}{lccccc}
$P M_{t}$ & 0.549 & 0.267 & 0.0539 & -0.0164 & 0.0180 \\
& $(0.356)$ & $(0.179)$ & $(0.0389)$ & $(0.0151)$ & $(0.0113)$ \\
\hline
\end{tabular}

2SLS

Ages 0-5

$\begin{array}{cccccc}P M_{t} & 3.890^{* * *} & 1.968^{* *} & 0.877^{* * *} & 0.0705^{*} & -0.125^{* *} \\ & (1.227) & (0.755) & (0.312) & (0.0392) & (0.0592)\end{array}$

Ages 1-5

$\begin{array}{cccccc}P M_{t} & 4.320^{* * *} & 2.255^{* *} & 1.046^{* * *} & 0.0548 & -0.0978^{*} \\ & (1.392) & (0.872) & (0.364) & (0.0411) & (0.0535)\end{array}$

Ages 0-1

\begin{tabular}{lccccc}
$P M_{t}$ & 1.740 & 0.532 & 0.0273 & $0.149^{*}$ & 0.0430 \\
& $(1.296)$ & $(0.627)$ & $(0.170)$ & $(0.0811)$ & $(0.0392)$ \\
\hline Number of districts & 77 & 77 & 77 & 77 & 77 \\
Number of days & 1,096 & 1,096 & 1,096 & 1,096 & 1,096 \\
Observations & 78,956 & 78,956 & 78,956 & 78,956 & 78,956 \\
\hline
\end{tabular}

Table shows the results for the second stage adding wind speed bins as controls.Standard errors in parentheses are two-way clustered by district and day. To check significance: ${ }^{* * *} \mathrm{p}<0.01,{ }^{* *} \mathrm{p}<0.05,{ }^{*}$ $\mathrm{p}<0.1$.

Results keep almost the same as coefficients of main specification, confirming that pollutants come mainly from non-stationary sources, otherwise the bins fixed effect would capture this stationary source of pollution every time the wind blows from it, expressively 
changing PM coefficient. 



\section{Concluding remarks}

Pollution emissions cause negative externalities on human health, especially of vulnerable groups such as children. We propose a 2SLS model to estimate the impact of PM 10 on hospitalizations in São Paulo Metropolitan Area between 2015 and 2017. We intend to contribute not only to the literature that measures the impacts of pollution on health in developing countries, but also to cleaner air regulations in the most populated region of the country - São Paulo Metropolitan Area represents approximately 10\% out of Brazilian population.

We deal with the endogeneity of air pollution exposure, due to potential adaptation of individuals and economic changes, using wind speed as instrument for air pollution. The results show that PM 10 positively affects hospitalizations for respiratory disease in the short term for children between one and five years old. We verify an increasing in acute episodes of asthma and admissions caused by infectious diseases. The channel by which pollution affects infectious diseases deserves more attention, since the role of air pollution in facilitating respiratory is not yet well understood (BRAGA et al., 2001a).

Our results are conditioned to the quality of data and to the construction of our database. Gouveia and Fletcher (2000a) highlight the possibility of selection bias, since we do not have information for out-of-pocket and insured hospitalization and, as a consequence, the wealthier part of population is not represented. Despite this limitation, verifying the impacts for low income people are important for policymakers. About the quality of admission information, especially related to the diagnosis, the authors found a considerable agreement.

The lack of significance of coefficients for infants may be related to our instrumental variable, which is only relevant to capture an exogenous air pollution if individuals have outdoor activities, which might not be frequent for this age group. Another limitation is that we only have georeferenced data for hospitalization, not mortality, which prevent us of verifying pollution effects on death within SPMA. On the other hand, our data only count hospitalizations, which are an extreme episode of health problem ${ }^{12}$, not counting for ambulatory or less severe cases, also because of unavailable georeferenced data. It does not invalidate our results, but suggest the impacts on health may be higher.

Finally, we discuss SUS infrastructure constraints, which are an open question. We find that public system is able to absorb an exceeded demand for beds, although an analysis about the quality of public service is still required. Furthermore, the costs of maintaining an infrastructure ready to meet avoidable hospitalizations should be taken

12 This problem is also discussed by Gouveia and Fletcher (2000a). 
into consideration when deciding which is costless: costing hospitalization or imposing stricter emission limits ${ }^{13}$.

13 We should also take into account that government has more expenses than those related to hospitalizations, for example ambulatory services and medicines, once drugs for chronic diseases such as asthma can be purchased either for free or at a reduced price through the Popular Pharmacy Program. 


\section{Reference List}

ALLEN, R. W. et al. An assessment of air pollution and its attributable mortality in ulaanbaatar, mongolia. Air Quality, Atmosphere \& Health, Springer, v. 6, n. 1, p. 137-150, 2013. Cited on page 36 .

ANDERSON, M. L. As the wind blows: The effects of long-term exposure to air pollution on mortality. 2015. Cited on page 22.

ARCEO, E.; HANNA, R.; OLIVA, P. Does the effect of pollution on infant mortality differ between developing and developed countries? evidence from mexico city. The Economic Journal, Wiley Online Library, v. 126, n. 591, p. 257-280, 2016. Cited 2 times on pages 19 and 43 .

ATLAS da Saúde da Cidade de São Paulo./Secretaria da Saúde. Instituto Via Pública/ São Paulo: Instituto Via Pública, 2011. Cited on page 26.

BELL, M. L.; KIM, J. Y.; DOMINICI, F. Potential confounding of particulate matter on the short-term association between ozone and mortality in multisite time-series studies. Environmental Health Perspectives, National Institute of Environmental Health Science, v. 115, n. 11, p. 1591, 2007. Cited 3 times on pages 22, 28, and 50.

BRAGA, A. et al. Poluição atmosférica e saúde humana. Revista USP, n. 51, p. 58-71, 2001. Cited 4 times on pages 23, 24, 27, and 57.

BRAGA, A. L. et al. Health effects of air pollution exposure on children and adolescents in são paulo, brazil. Pediatric pulmonology, Citeseer, v. 31, n. 2, p. 106-113, 2001. Cited on page 28 .

BRAUER ANDREW CHURG, M. Ambient atmospheric particles in the airways of human lungs. Ultrastructural pathology, Taylor \& Francis, v. 24, n. 6, p. 353-361, 2000. Cited on page 27.

CETESB, C. A. d. E. d. S. P. Emissões veiculares no estado de são paulo 2015. São Paulo: CETESB, 2016. Cited 2 times on pages 23 and 24.

CETESB, C. A. d. E. d. S. P. Qualidade do ar no estado de são paulo 2016. CETESB, 2017. Cited on page 20.

CHAY, K.; DOBKIN, C.; GREENSTONE, M. The clean air act of 1970 and adult mortality. Journal of risk and uncertainty, Springer, v. 27, n. 3, p. 279-300, 2003. Cited on page 19 .

CHURG, A. et al. Chronic exposure to high levels of particulate air pollution and small airway remodeling. Environmental Health Perspectives, National Institute of Environmental Health Science, v. 111, n. 5, p. 714, 2003. Cited on page 27.

CLAY, K.; LEWIS, J.; SEVERNINI, E. Canary in a Coal Mine: Infant Mortality, Property Values, and Tradeoffs Associated with Mid-20th Century Air Pollution. [S.1.], 2016. Cited 2 times on pages 20 and 43. 
COELHO, S. T. et al. Brazilian sugarcane ethanol: lessons learned [1]. Energy for sustainable development, Elsevier, v. 10, n. 2, p. 26-39, 2006. Cited on page 24.

CURRIE, J.; NEIDELL, M. Air pollution and infant health: What can we learn from california's recent experience? The Quarterly Journal of Economics, Oxford Journals, v. 120, n. 3, p. 1003-1030, 2005. Cited 3 times on pages 19, 43, and 50.

CURRIE, J.; NEIDELL, M.; SCHMIEDER, J. F. Air pollution and infant health: Lessons from new jersey. Journal of health economics, v. 28, n. 3, p. 688-703, 2009. Cited on page 43.

CURRIE, J.; WALKER, R. Traffic congestion and infant health: Evidence from e-zpass. American Economic Journal: Applied Economics, v. 3, n. 1, p. 65-90, 2011. Cited 3 times on pages 19,20 , and 43 .

CURRIE, J. et al. What do we know about short-and long-term effects of early-life exposure to pollution? Annu. Rev. Resour. Econ., Annual Reviews, v. 6, n. 1, p. 217-247, 2014. Cited 3 times on pages 21, 28, and 29.

DERYUGINA, T. et al. The Mortality and Medical Costs of Air Pollution: Evidence from Changes in Wind Direction. [S.1.], 2016. Cited 2 times on pages 22 and 36.

DESCHÊNES, O.; GREENSTONE, M.; SHAPIRO, J. S. Defensive investments and the demand for air quality: Evidence from the nox budget program. American Economic Review, v. 107, n. 10, p. 2958-89, 2017. Cited on page 19.

DOMINICI, F.; GREENSTONE, M.; SUNSTEIN, C. R. Particulate matter matters. Science, American Association for the Advancement of Science, v. 344, n. 6181, p. 257-259, 2014. Cited on page 20.

FLETCHER, J. M.; GREEN, J. C.; NEIDELL, M. J. Long term effects of childhood asthma on adult health. Journal of health economics, Elsevier, v. 29, n. 3, p. 377-387, 2010. Cited 2 times on pages 21 and 29.

GOUVEIA, N.; FLETCHER, T. Respiratory diseases in children and outdoor air pollution in sao paulo, brazil: a time series analysis. Occupational and environmental medicine, BMJ Publishing Group Ltd, v. 57, n. 7, p. 477-483, 2000. Cited on page 57.

GOUVEIA, N.; FLETCHER, T. Time series analysis of air pollution and mortality: effects by cause, age and socioeconomic status. Journal of epidemiology and community health, BMJ Publishing Group Ltd, v. 54, n. 10, p. 750-755, 2000. Cited on page 28.

GREENSTONE, M.; JACK, B. K. Envirodevonomics: A research agenda for an emerging field. Journal of Economic Literature, v. 53, n. 1, p. 5-42, 2015. Cited on page 19.

HANLON, W. W.; TIAN, Y. Killer cities: Past and present. American Economic Review, v. 105 , n. 5 , p. 570-75, 2015. Cited on page 20.

HANNA, R.; OLIVA, P. The effect of pollution on labor supply: Evidence from a natural experiment in mexico city. Journal of Public Economics, Elsevier, v. 122, p. 68-79, 2015. Cited 2 times on pages 22 and 36. 
HE, J.; GOUVEIA, N.; SALVO, A. External effects of diesel trucks circulating inside the sao paulo megacity. Journal of the European Economic Association, 2016. Cited on page 21.

HERRNSTADT, E.; MUEHLEGGER, E. Air Pollution and Criminal Activity: Evidence from Chicago Microdata. [S.l.], 2015. Cited 2 times on pages 22 and 36.

JACOBI, P. et al. Poluição do ar em são paulo e resposta da ação pública. Cadernos Cedec, CEDEC São Paulo, v. 60, 1997. Cited on page 24.

JAYACHANDRAN, S. Air quality and early-life mortality evidence from indonesia's wildfires. Journal of Human resources, University of Wisconsin Press, v. 44, n. 4, p. 916-954, 2009. Cited 2 times on pages 22 and 43.

KAMPA, M.; CASTANAS, E. Human health effects of air pollution. Environmental pollution, Elsevier, v. 151, n. 2, p. 362-367, 2008. Cited on page 28.

KELLY, F.; FUSSELL, J. Air pollution and airway disease. Clinical $\&$ Experimental Allergy, Wiley Online Library, v. 41, n. 8, p. 1059-1071, 2011. Cited on page 27.

MACINKO, J.; HARRIS, M. J. Brazil's family health strategy-delivering communitybased primary care in a universal health system. New England Journal of Medicine, Mass Medical Soc, v. 372, n. 23, p. 2177-2181, 2015. Cited on page 26.

MARTINS, L. D.; ANDRADE, M. de F. Ozone formation potentials of volatile organic compounds and ozone sensitivity to their emission in the megacity of são paulo, brazil. Water, air, and soil pollution, Springer, v. 195, n. 1-4, p. 201-213, 2008. Cited 2 times on pages 50 and 51 .

MIRANDA, R. M. de et al. Urban air pollution: a representative survey of pm2. 5 mass concentrations in six brazilian cities. Air quality, atmosphere $\&$ health, Springer, v. 5, n. 1, p. 63-77, 2012. Cited on page 23.

MULLER, N. Z.; RUUD, P. A. What forces dictate the design of pollution monitoring networks? Environmental Modeling \& Assessment, Springer, v. 23, n. 1, p. 1-14, 2018. Cited on page 30 .

NEIDELL, M. J. Air pollution, health, and socio-economic status: the effect of outdoor air quality on childhood asthma. Journal of health economics, Elsevier, v. 23, n. 6, p. 1209-1236, 2004. Cited 3 times on pages 30, 35, and 43.

NIVEN, R. K. Ethanol in gasoline: environmental impacts and sustainability review article. Renewable and Sustainable Energy Reviews, Elsevier, v. 9, n. 6, p. 535-555, 2005. Cited on page 24 .

ORLANDO, J. P. et al. Ozone precursors for the são paulo metropolitan area. Science of the total environment, Elsevier, v. 408, n. 7, p. 1612-1620, 2010. Cited 2 times on pages 23 and 72 .

PAIM, J. et al. The brazilian health system: history, advances, and challenges. The Lancet, Elsevier, v. 377, n. 9779, p. 1778-1797, 2011. Cited 2 times on pages 25 and 29. 
POPE, C. A. Respiratory disease associated with community air pollution and a steel mill, utah valley. American Journal of Public Health, American Public Health Association, v. 79 , n. 5 , p. $623-628,1989$. Cited on page 27.

POPE, C. A. Epidemiology of fine particulate air pollution and human health: biologic mechanisms and who's at risk? Environmental health perspectives, National Institute of Environmental Health Science, v. 108, n. Suppl 4, p. 713, 2000. Cited 2 times on pages 27 and 28.

POPE, C. A.; DOCKERY, D. W.; SCHWARTZ, J. Review of epidemiological evidence of health effects of particulate air pollution. Inhalation toxicology, Taylor \& Francis, v. 7, n. 1, p. 1-18, 1995. Cited on page 19.

SALVO, A. et al. Reduced ultrafine particle levels in são paulo's atmosphere during shifts from gasoline to ethanol use. Nature communications, Nature Publishing Group, v. 8, n. 1, p. 77, 2017. Cited on page 22 .

SALVO, A.; GEIGER, F. M. Reduction in local ozone levels in urban são paulo due to a shift from ethanol to gasoline use. Nature Geoscience, Nature Publishing Group, v. 7, n. 6, p. 450, 2014. Cited 3 times on pages 20, 21, and 22 .

SALVO, A.; WANG, Y. Ethanol-blended gasoline policy and ozone pollution in sao paulo. Journal of the Association of Environmental and Resource Economists, University of Chicago Press Chicago, IL, v. 4, n. 3, p. 731-794, 2017. Cited 3 times on pages 22, 50, and 51 .

SARAVIA, J. et al. Particulate matter containing environmentally persistent free radicals and adverse infant respiratory health effects: a review. Journal of biochemical and molecular toxicology, Wiley Online Library, v. 27, n. 1, p. 56-68, 2013. Cited on page 27.

SCHLENKER, W.; WALKER, W. R. Airports, air pollution, and contemporaneous health. The Review of Economic Studies, Oxford University Press, v. 83, n. 2, p. 768-809, 2016. Cited 6 times on pages 19, 30, 36, 37, 43, and 48.

SEAMAN, N. L. Meteorological modeling for air-quality assessments. Atmospheric environment, Elsevier, v. 34, n. 12, p. 2231-2259, 2000. Cited on page 36.

STOCK, J. H.; YOGO, M. Testing for weak instruments in linear iv regression. In: . Identification and Inference for Econometric Models: Essays in Honor of Thomas Rothenberg. [S.l.]: Cambridge University Press, 2005. p. 80-108. Cited on page 40.

WHO, W. H. O. et al. Who expert consultation: Available evidence for the future update of the who global air quality guidelines (aqgs). WHO, 2015. Cited 4 times on pages 23, 27,28 , and 31 .

ZELIKOFF, J. T. et al. A role for associated transition metals in the immunotoxicity of inhaled ambient particulate matter. Environmental Health Perspectives, National Institute of Environmental Health Science, v. 110, n. Suppl 5, p. 871, 2002. Cited on page 27. 
Appendix 



\section{APPENDIX A - First Stage}

Table $1-$ First stage $-3 \mathrm{~km}$

\begin{tabular}{|c|c|c|c|}
\hline & Ages $0-5$ & Ages 1-5 & Ages 0-1 \\
\hline & $P M_{t}$ & $P M_{t}$ & $P M_{t}$ \\
\hline$w s_{t}$ & $\begin{array}{c}-0.650^{* * *} * \\
(0.0720)\end{array}$ & $\begin{array}{c}-0.650^{* * *} \\
(0.0721)\end{array}$ & $\begin{array}{c}-0.649 * * * \\
(0.0718)\end{array}$ \\
\hline$w s_{t-1}$ & $\begin{array}{c}-0.172^{* * * *} \\
(0.0442)\end{array}$ & $\begin{array}{c}-0.172^{* * *} \\
(0.0442)\end{array}$ & $\begin{array}{c}-0.172^{* * *} \\
(0.0442)\end{array}$ \\
\hline F-statistic & 49.50 & 49.47 & 49.65 \\
\hline Number of districts & 44 & 44 & 44 \\
\hline Number of days & 1,096 & 1,096 & 1,096 \\
\hline Observations & 44,280 & 44,280 & 44,280 \\
\hline
\end{tabular}

Table shows results of the first stage for districts no further than $3 \mathrm{~km}$. To check significance: $* * * \mathrm{p}<0.01$, ** $\mathrm{p}<0.05,{ }^{*} \mathrm{p}<0.1$.

Table 2 - First stage $-7 \mathrm{~km}$

\begin{tabular}{|c|c|c|c|}
\hline & Ages 0-5 & Ages 1-5 & Ages 0-1 \\
\hline & $P M_{t}$ & $P M_{t}$ & $P M_{t}$ \\
\hline$w s_{t}$ & $\begin{array}{c}-0.661^{* * *} \\
(0.0527)\end{array}$ & $\begin{array}{c}-0.661^{* * *} \\
(0.0527)\end{array}$ & $\begin{array}{c}-0.660 * * * \\
(0.0526)\end{array}$ \\
\hline$w s_{t-1}$ & $\begin{array}{c}-0.201^{* * *} \\
(0.0459)\end{array}$ & $\begin{array}{c}-0.201^{* * *} \\
(0.0459)\end{array}$ & $\begin{array}{c}-0.201^{* * *} \\
(0.0458)\end{array}$ \\
\hline F-statistic & 97.86 & 97.81 & 98.13 \\
\hline Number of districts & 95 & 95 & 95 \\
\hline Number of days & 1,096 & 1,096 & 1,096 \\
\hline Observations & 96,101 & 96,101 & 96,101 \\
\hline
\end{tabular}

Table shows results of the first stage for districts no further than $7 \mathrm{~km}$. To check significance: *** $\mathrm{p}<0.01$, ** $\mathrm{p}<0.05,{ }^{*} \mathrm{p}<0.1$. 
Table 3 - First stage - 10km

\begin{tabular}{|c|c|c|c|}
\hline & Ages 0-5 & Ages 1-5 & Ages 0-1 \\
\hline & $P M_{t}$ & $P M_{t}$ & $P M_{t}$ \\
\hline$w s_{t}$ & $\begin{array}{c}-0.663^{* * *} \\
(0.0504)\end{array}$ & $\begin{array}{c}-0.663^{* * *} \\
(0.0504)\end{array}$ & $\begin{array}{c}-0.663^{* * *} \\
(0.0505)\end{array}$ \\
\hline$w s_{t-1}$ & $\begin{array}{c}-0.200^{* * *} \\
(0.0442)\end{array}$ & $\begin{array}{c}-0.200^{* * *} \\
(0.0442)\end{array}$ & $\begin{array}{c}-0.200^{* * *} \\
(0.0442)\end{array}$ \\
\hline F-statistic & 108.82 & 108.80 & 108.90 \\
\hline Number of districts & 107 & 107 & 107 \\
\hline Number of days & 1,096 & 1,096 & 1,096 \\
\hline Observations & 106,980 & 106,980 & 106,980 \\
\hline
\end{tabular}

Table shows results of the first stage for districts no further than $10 \mathrm{~km}$. To check significance: $* * * \mathrm{p}<0.01, * *$ $\mathrm{p}<0.05,{ }^{*} \mathrm{p}<0.1$. 


\section{APPENDIX B - Second stage}

\section{B.1 Main specification}

Table 4 - Second stage - 3km

\begin{tabular}{|c|c|c|c|c|c|}
\hline & \multicolumn{4}{|c|}{ Hospitalization rate } & \multirow{2}{*}{$\frac{\text { Days }}{\text { Respiratory }}$} \\
\hline & Respiratory & Pneumonia & Asthma & Influenza & \\
\hline \multicolumn{6}{|l|}{$\begin{array}{l}\text { OLS } \\
\text { Ages } 0-5\end{array}$} \\
\hline$P M_{t}$ & $\begin{array}{c}1.366^{* * *} \\
(0.401)\end{array}$ & $\begin{array}{l}0.426^{*} \\
(0.234)\end{array}$ & $\begin{array}{c}0.0205 \\
(0.0726)\end{array}$ & $\begin{array}{c}0.0531^{* *} \\
(0.0226)\end{array}$ & $\begin{array}{c}0.0578 \\
(0.0405)\end{array}$ \\
\hline \multicolumn{6}{|l|}{ Ages 1-5 } \\
\hline$P M_{t}$ & $\begin{array}{c}1.434^{* * *} \\
(0.498)\end{array}$ & $\begin{array}{c}0.427 \\
(0.295)\end{array}$ & $\begin{array}{c}0.0164 \\
(0.0896)\end{array}$ & $\begin{array}{c}0.0639^{* *} \\
(0.0264)\end{array}$ & $\begin{array}{c}0.0628 \\
(0.0444)\end{array}$ \\
\hline \multicolumn{6}{|l|}{ Ages 0-1 } \\
\hline$P M_{t}$ & $\begin{array}{l}1.023^{* *} \\
(0.497)\end{array}$ & $\begin{array}{c}0.420 \\
(0.322)\end{array}$ & $\begin{array}{c}0.0415 \\
(0.0538)\end{array}$ & $\begin{array}{c}-0.000563 \\
(0.0257) \\
\end{array}$ & $\begin{array}{c}0.0177 \\
(0.0132)\end{array}$ \\
\hline \multicolumn{6}{|l|}{$\begin{array}{l}\text { 2SLS } \\
\text { Ages } 0-5\end{array}$} \\
\hline$P M_{t}$ & $\begin{array}{c}4.269 * * * \\
(1.162)\end{array}$ & $\begin{array}{l}1.711^{* *} \\
(0.775)\end{array}$ & $\begin{array}{c}0.891^{* *} \\
(0.345)\end{array}$ & $\begin{array}{c}0.103 \\
(0.0645)\end{array}$ & $\begin{array}{l}-0.176^{*} \\
(0.0879)\end{array}$ \\
\hline \multicolumn{6}{|l|}{ Ages 1-5 } \\
\hline$P M_{t}$ & $\begin{array}{c}4.776^{* * * *} \\
(1.280)\end{array}$ & $\begin{array}{c}2.093^{* *} \\
(0.898)\end{array}$ & $\begin{array}{c}1.109^{* * *} \\
(0.400)\end{array}$ & $\begin{array}{c}0.0831 \\
(0.0648)\end{array}$ & $\begin{array}{c}-0.111 \\
(0.0777)\end{array}$ \\
\hline \multicolumn{6}{|c|}{ 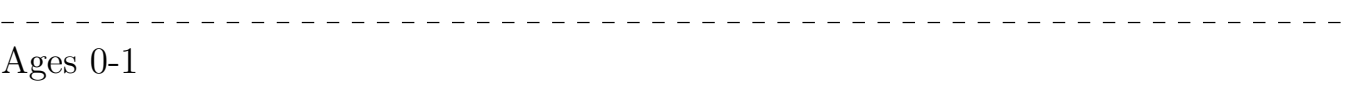 } \\
\hline$P M_{t}$ & $\begin{array}{c}1.745 \\
(1.922) \\
\end{array}$ & $\begin{array}{l}-0.188 \\
(0.777) \\
\end{array}$ & $\begin{array}{l}-0.197 \\
(0.254) \\
\end{array}$ & $\begin{array}{c}0.204 \\
(0.134) \\
\end{array}$ & $\begin{array}{l}0.00475 \\
(0.0602) \\
\end{array}$ \\
\hline Number of districts & 44 & 44 & 44 & 44 & 44 \\
\hline Number of days & 1,096 & 1,096 & 1,096 & 1,096 & 1,096 \\
\hline Observations & 44,280 & 44,280 & 44,280 & 44,280 & 44,280 \\
\hline
\end{tabular}

Table shows the results of second stage for districts no further than $3 \mathrm{~km}$. To check significance: ${ }^{* * *} \mathrm{p}<0.01,{ }^{* *} \mathrm{p}<0.05,{ }^{*} \mathrm{p}<0.1$. 
Table 5 - Second stage - $7 \mathrm{~km}$

\begin{tabular}{|c|c|c|c|c|c|}
\hline & \multicolumn{4}{|c|}{ Hospitalization rate } & \multirow{2}{*}{$\frac{\text { Days }}{\text { Respiratory }}$} \\
\hline & Respiratory & Pneumonia & Asthma & Influenza & \\
\hline \multicolumn{6}{|l|}{$\begin{array}{l}\text { OLS } \\
\text { Ages 0-5 }\end{array}$} \\
\hline$P M_{t}$ & $\begin{array}{l}0.698^{*} \\
(0.365)\end{array}$ & $\begin{array}{c}0.296 \\
(0.220)\end{array}$ & $\begin{array}{c}0.0529 \\
(0.0825)\end{array}$ & $\begin{array}{c}0.0262^{* *} \\
(0.0124)\end{array}$ & $\begin{array}{c}0.0270 \\
(0.0228)\end{array}$ \\
\hline \multicolumn{6}{|l|}{ Ages 1-5 } \\
\hline$P M_{t}$ & $\begin{array}{l}0.761^{*} \\
(0.427)\end{array}$ & $\begin{array}{c}0.301 \\
(0.260)\end{array}$ & $\begin{array}{c}0.0533 \\
(0.0965)\end{array}$ & $\begin{array}{c}0.0341^{* *} \\
(0.0142)\end{array}$ & $\begin{array}{c}0.0282 \\
(0.0237)\end{array}$ \\
\hline \multicolumn{6}{|c|}{$\begin{array}{l}--------------------------------------------------------1 \\
\text { Ages } 0-1\end{array}$} \\
\hline$P M_{t}$ & $\begin{array}{c}0.381 \\
(0.312)\end{array}$ & $\begin{array}{l}0.273^{*} \\
(0.152)\end{array}$ & $\begin{array}{c}0.0515 \\
(0.0358)\end{array}$ & $\begin{array}{l}-0.0137 \\
(0.0119)\end{array}$ & $\begin{array}{c}0.0109 \\
(0.00923)\end{array}$ \\
\hline \multicolumn{6}{|l|}{$\begin{array}{l}\text { 2SLS } \\
\text { Ages } 0-5\end{array}$} \\
\hline$P M_{t}$ & $\begin{array}{l}2.278^{*} \\
(1.337)\end{array}$ & $\begin{array}{l}1.513^{* *} \\
(0.741)\end{array}$ & $\begin{array}{l}0.724^{* *} \\
(0.286)\end{array}$ & $\begin{array}{c}0.0720^{* *} \\
(0.0360)\end{array}$ & $\begin{array}{c}-0.151^{* * *} \\
(0.0530)\end{array}$ \\
\hline \multicolumn{6}{|c|}{$\begin{array}{l}------------------------------------------------ \\
\text { Ages } 1-5\end{array}$} \\
\hline$P M_{t}$ & $\begin{array}{l}2.584^{*} \\
(1.514)\end{array}$ & $\begin{array}{l}1.759 * * \\
(0.865)\end{array}$ & $\begin{array}{c}0.853^{* *} \\
(0.335)\end{array}$ & $\begin{array}{l}0.0625^{*} \\
(0.0370)\end{array}$ & $\begin{array}{r}-0.123^{* *} \\
(0.0483)\end{array}$ \\
\hline \multicolumn{6}{|c|}{$\begin{array}{l}\text { Ages } 0-1 \\
\text { Agen }\end{array}$} \\
\hline$P M_{t}$ & $\begin{array}{c}0.743 \\
(1.043)\end{array}$ & $\begin{array}{c}0.276 \\
(0.458)\end{array}$ & $\begin{array}{c}0.0715 \\
(0.132)\end{array}$ & $\begin{array}{c}0.120^{*} \\
(0.0662)\end{array}$ & $\begin{array}{c}0.00181 \\
(0.0330)\end{array}$ \\
\hline Number of districts & 95 & 95 & 95 & 95 & 95 \\
\hline Number of days & 1,096 & 1,096 & 1,096 & 1,096 & 1,096 \\
\hline Observations & 96,101 & 96,101 & 96,101 & 96,101 & 96101 \\
\hline
\end{tabular}

Table shows the results of second stage for districts no further than $7 \mathrm{~km}$. To check significance: ${ }^{* * *} \mathrm{p}<0.01,{ }^{* *} \mathrm{p}<0.05,{ }^{*} \mathrm{p}<0.1$. 
Table 6 - Second stage - 10km

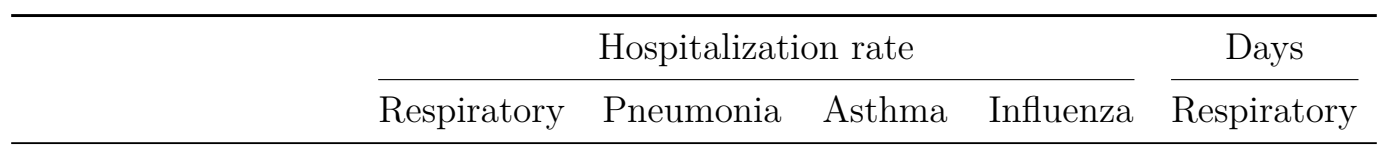

OLS

Ages 0-5

$\begin{array}{lccccc}P M_{t} & 0.725^{* *} & 0.405^{*} & 0.0628 & 0.0295^{* *} & 0.0360^{*} \\ & (0.348) & (0.208) & (0.0759) & (0.0124) & (0.0214)\end{array}$

Ages 1-5

$\begin{array}{lccccc}P M_{t} & 0.789^{*} & 0.417^{*} & 0.0701 & 0.0352^{* *} & 0.0353 \\ & (0.408) & (0.246) & (0.0892) & (0.0139) & (0.0220)\end{array}$

Ages $0-1$

\begin{tabular}{cccccc}
$P M_{t}$ & 0.401 & $0.345^{* *}$ & 0.0265 & 0.000462 & 0.0124 \\
& $(0.282)$ & $(0.143)$ & $(0.0394)$ & $(0.0164)$ & $(0.00829)$ \\
\hline
\end{tabular}

\section{SLS}

Ages 0-5

$\begin{array}{lccccc}P M_{t} & 1.447 & 1.479^{* *} & 0.595^{* *} & 0.0787^{* *} & -0.147^{* * *} \\ & (1.371) & (0.683) & (0.266) & (0.0341) & (0.0506)\end{array}$

Ages 1-5

$\begin{array}{cccccc}P M_{t} & 1.646 & 1.703^{* *} & 0.714^{* *} & 0.0696^{* *} & -0.132^{* * *} \\ & (1.566) & (0.796) & (0.309) & (0.0348) & (0.0475)\end{array}$

Ages 0-1

\begin{tabular}{lccccc}
$P M_{t}$ & 0.443 & 0.349 & -0.00731 & $0.124^{* *}$ & 0.00773 \\
& $(0.958)$ & $(0.408)$ & $(0.136)$ & $(0.0612)$ & $(0.0305)$ \\
\hline Number of districts & 107 & 107 & 107 & 107 & 107 \\
Number of days & 1,096 & 1,096 & 1,096 & 1,096 & 1,096 \\
Observations & 106,980 & 106,980 & 106,980 & 106,980 & 106980 \\
\hline
\end{tabular}

Table shows the results of second stage for districts no further than $10 \mathrm{~km}$. To check significance: ${ }^{* * *} \mathrm{p}<0.01,{ }^{* *} \mathrm{p}<0.05,{ }^{*} \mathrm{p}<0.1$. 


\section{B.2 Additional results}

Table 7 - Second stage - one lag

\begin{tabular}{|c|c|c|c|c|c|}
\hline & \multicolumn{4}{|c|}{ Hospitalization rate } & \multirow{2}{*}{$\frac{\text { Days }}{\text { Respiratory }}$} \\
\hline & Respiratory & Pneumonia & Asthma & Influenza & \\
\hline \multicolumn{6}{|l|}{ Ages $0-5$} \\
\hline$P M_{t}$ & $\begin{array}{c}1.176 \\
(1.369)\end{array}$ & $\begin{array}{c}0.479 \\
(0.925)\end{array}$ & $\begin{array}{c}0.229 \\
(0.341)\end{array}$ & $\begin{array}{c}0.0860 \\
(0.0598)\end{array}$ & $\begin{array}{c}-0.186^{* *} \\
(0.0906)\end{array}$ \\
\hline$P M_{t-1}$ & $\begin{array}{c}3.997^{* * *} \\
(1.454)\end{array}$ & $\begin{array}{l}2.240 * * \\
(0.918)\end{array}$ & $\begin{array}{c}1.034^{* * *} \\
(0.333)\end{array}$ & $\begin{array}{c}0.0111 \\
(0.0482)\end{array}$ & $\begin{array}{c}0.0779 \\
(0.143)\end{array}$ \\
\hline Cumulative & $\begin{array}{l}5.17^{* * *} \\
(1.404)\end{array}$ & $\begin{array}{c}2.72^{* * *} \\
(0.827)\end{array}$ & $\begin{array}{l}1.26^{* * *} \\
(0.383)\end{array}$ & $\begin{array}{l}0.10^{* *} \\
(0.041)\end{array}$ & $\begin{array}{c}-0.11 \\
(0.104)\end{array}$ \\
\hline \multicolumn{6}{|l|}{ Ages 1-5 } \\
\hline$P M_{t}$ & $\begin{array}{c}1.556 \\
(1.590)\end{array}$ & $\begin{array}{c}0.775 \\
(1.067)\end{array}$ & $\begin{array}{c}0.270 \\
(0.406)\end{array}$ & $\begin{array}{c}0.0783 \\
(0.0646)\end{array}$ & $\begin{array}{c}-0.121^{*} \\
(0.0721)\end{array}$ \\
\hline$P M_{t-1}$ & $\begin{array}{l}4.127^{* *} \\
(1.675)\end{array}$ & $\begin{array}{l}2.265^{* *} \\
(1.053)\end{array}$ & $\begin{array}{c}1.232^{* * *} \\
(0.398)\end{array}$ & $\begin{array}{r}-0.00463 \\
(0.0597)\end{array}$ & $\begin{array}{c}0.0235 \\
(0.123) \\
-\end{array}$ \\
\hline Cumulative & $\begin{array}{c}5.68^{* * *} \\
(1.608) \\
\end{array}$ & $\begin{array}{c}3.04^{* * *} \\
(0.960)\end{array}$ & $\begin{array}{l}1.50^{* * *} \\
(0.447)\end{array}$ & $\begin{array}{c}0.07 \\
(0.043) \\
\end{array}$ & $\begin{array}{c}-0.10 \\
(0.095) \\
\end{array}$ \\
\hline \multicolumn{6}{|l|}{ Ages $0-1$} \\
\hline$P M_{t}$ & $\begin{array}{c}-0.736 \\
(1.161)\end{array}$ & $\begin{array}{l}-1.011 \\
(0.699)\end{array}$ & $\begin{array}{l}0.0214 \\
(0.169)\end{array}$ & $\begin{array}{c}0.124 \\
(0.0905)\end{array}$ & $\begin{array}{c}-0.0318 \\
(0.0510)\end{array}$ \\
\hline$P M_{t-1}$ & $\begin{array}{c}3.355^{* *} \\
(1.274)\end{array}$ & $\begin{array}{c}2.119^{* * *} \\
(0.749)\end{array}$ & $\begin{array}{l}0.0420 \\
(0.157)\end{array}$ & $\begin{array}{c}0.0899 \\
(0.0803)\end{array}$ & $\begin{array}{c}0.0945^{* *} \\
(0.0446)\end{array}$ \\
\hline Cumulative & $\begin{array}{c}2.62^{*} \\
(1.419) \\
\end{array}$ & $\begin{array}{c}1.11^{*} \\
(0.629)\end{array}$ & $\begin{array}{c}0.06 \\
(0.194) \\
\end{array}$ & $\begin{array}{c}0.21^{* *} \\
(0.097) \\
\end{array}$ & $\begin{array}{c}0.06^{*} \\
(0.031) \\
\end{array}$ \\
\hline Number of districts & 77 & 77 & 77 & 77 & 77 \\
\hline Number of days & 1,095 & 1,095 & 1,095 & 1,095 & 1,095 \\
\hline Observations & 78,865 & 78,865 & 78,865 & 78,865 & 78,865 \\
\hline
\end{tabular}

Table shows the results of second stage for districts no further than $5 \mathrm{~km}$ including lagged pollution together with contemporaneous PM 10 as independent variable. Standard errors in parentheses are two-way clustered by district and day. To check significance: ${ }^{* * *} \mathrm{p}<0.01,{ }^{* *} \mathrm{p}<0.05,{ }^{*} \mathrm{p}<0.1$. 
Table 8 - Second stage - three lags

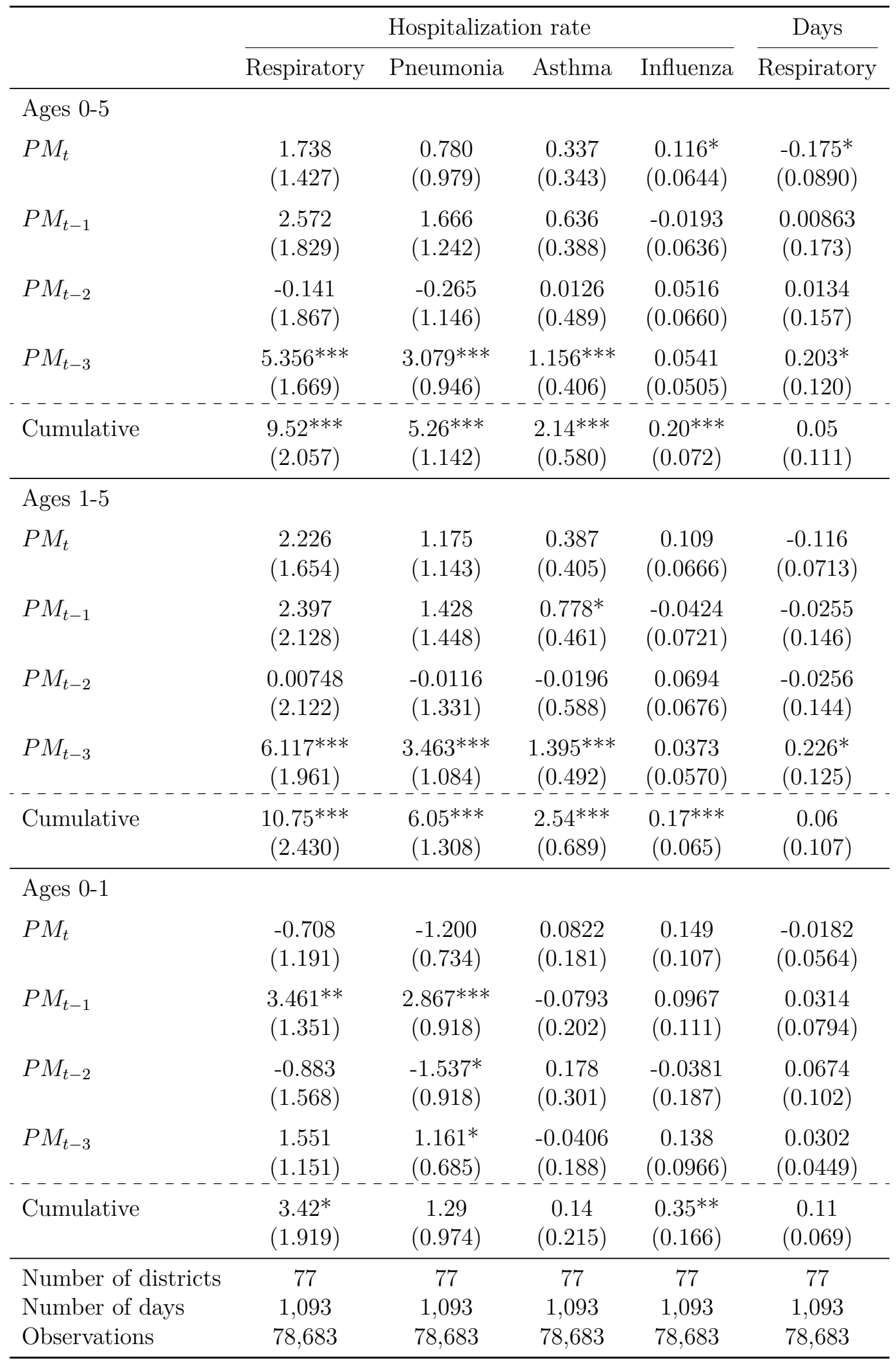

Table shows the results of second stage for districts no further than $5 \mathrm{~km}$ including lagged pollution together with contemporaneous PM 10 as independent variable. Standard errors in parentheses are two-way clustered by district and day. To check significance: ${ }^{* * *} \mathrm{p}<0.01,{ }^{* *} \mathrm{p}<0.05,{ }^{*} \mathrm{p}<0.1$. 

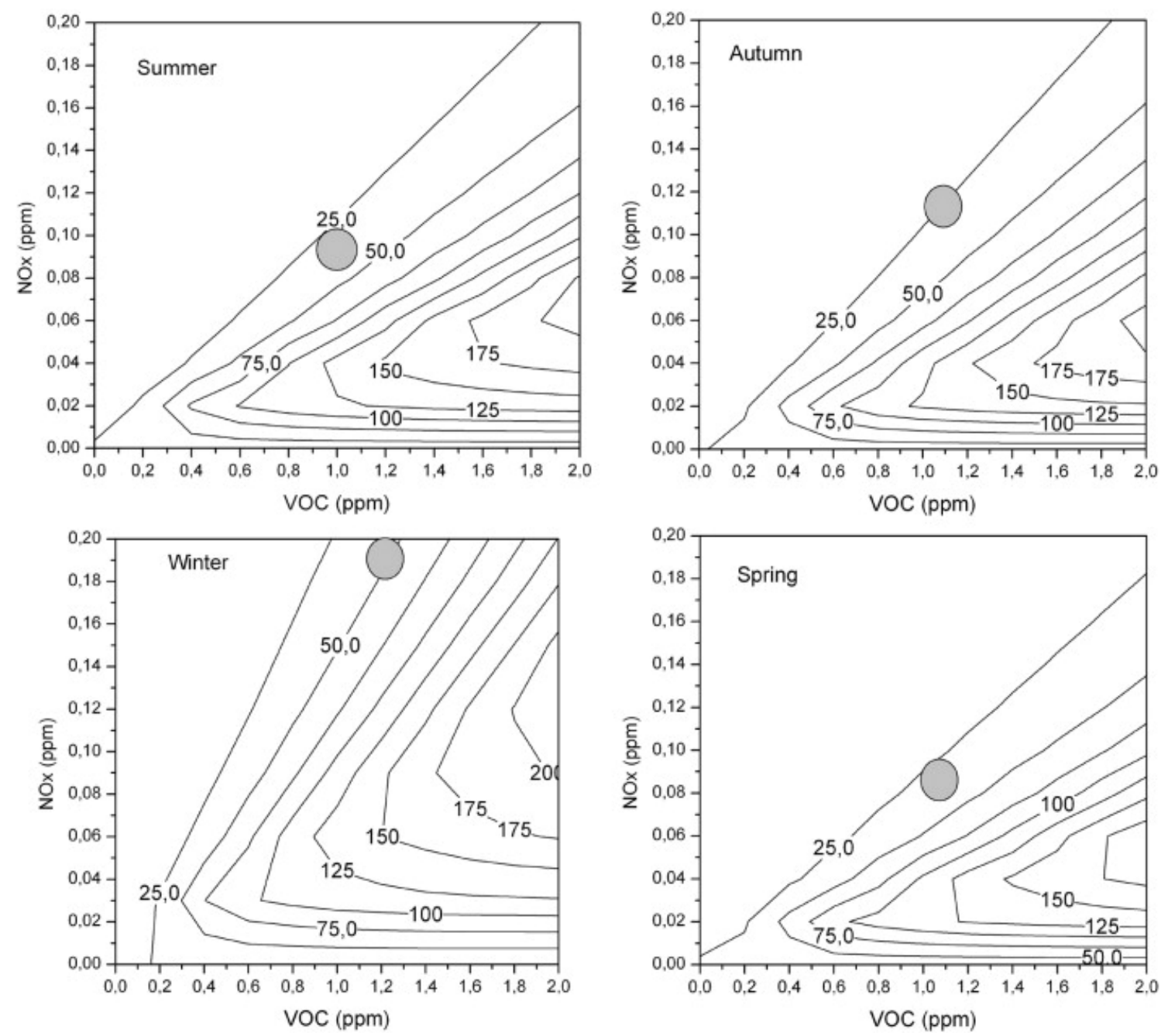

Figure obtained in Orlando et al. (2010). According to the authors, figures show "O3 isopleths (ppb) for several VOCs and NOx concentrations. The circled region is the average O3 concentration for each season of SPMA at University City area".

Figure 10 - Ozone formation by season at University City area in SPMA 